\title{
Assessing Marine Protected Areas Effectiveness: A Case Study with the Tobago Cays Marine Park
}

\author{
Alba Garcia Rodriguez, Lucia M. Fanning \\ Marine Affairs Program, Dalhousie University, Halifax, Nova Scotia, Canada \\ Email: Alba.GarciaRodriguez@dal.ca, lucia.fanning@dal.ca
}

How to cite this paper: Garcia Rodriguez, A. and Fanning, L.M. (2017) Assessing Marine Protected Areas Effectiveness: A Case Study with the Tobago Cays Marine Park. Open Journal of Marine Science, 7, 379-408. https://doi.org/10.4236/ojms.2017.73027

Received: May 31, 2017

Accepted: July 9, 2017

Published: July 12, 2017

Copyright $\odot 2017$ by authors and Scientific Research Publishing Inc. This work is licensed under the Creative Commons Attribution International License (CC BY 4.0).

http://creativecommons.org/licenses/by/4.0/

\begin{abstract}
Given the socio-economic consequences associated with declaring areas of ocean protected in order to achieve conservation objectives, this paper contributes to the growing global need to assess Marine Protected Areas (MPAs) as an effective management tool. It adds to the current body of knowledge on MPA effectiveness by conducting an evaluation of the Tobago Cays Marine Park (TCMP), located in St. Vincent and the Grenadines (SVG) in the eastern Caribbean, using a modified MPA effectiveness framework. Due to the limited information existing about the current performance of this MPA, this assessment also provides needed insight on the effect that the TCMP is having on the marine ecosystem, as well as its overall management performance. By comparing the performance of the MPA over a 10-year span (2007 and 2016), the results indicate that overall, the TCMP could be described as having limited success when key management categories of context, planning, input, process, output and outcomes are evaluated. In particular, efforts dedicated to planning, process and outcomes are assessed as deficient. Furthermore, the analysis revealed that efforts to realize the stated goals relating to conservation, public awareness and public education were being neglected. However, considerable effort was being expended by TCMP staff on achieving the remaining goal focusing on deriving economic benefits from touristic activities in the Park. Preliminary field research examining the effects of the TCMP on the abundance and density of an economically important species, Lobatus gigas, (commonly referred to as the queen conch) showed the TCMP as having no effect towards conch protection. The results and recommendations of this study, combined with continued monitoring of a recommended targeted suite of indicators, could contribute to better-informed adaptive MPA management, leading to progress towards the achievement of the stated goals for the TCMP.
\end{abstract}

\section{Keywords}

Marine Protected Areas, MPA Effectiveness, St. Vincent and the Grenadines, 
Tobago Cays Marine Park, Evaluation Framework, Queen Conch

\section{Introduction}

During the past decades, human activities have severely modified and shaped the marine environment. Fishing practices, fossil fuels consumption, the need for mineral products, and land-based pollution are some of the activities that have been generating important changes in the ocean [1] [2]. The consequences of these activities, particularly when highly developed, often result in negative impacts on the marine biota and the humans who depend on them [3] [4] [5] [6]. These impacts have over time brought attention to the need for better marine management and conservation measures [7] [8] [9] [10]. Effective marine management is the required mechanism to ensure the sustainable use of the ocean's resources and to develop conservation strategies. Through marine management and conservation, the impacts of climate change, overfishing, pollution, etc. can be mitigated, and ecosystem resilience can be enhanced [11] [12] [13].

In order to maintain functional and productive marine ecosystems, it is essential to minimize or remove the threats to which these systems are exposed. One response for minimizing these threats is the use of Marine Protected Areas (MPAs). MPAs can be defined as clearly outlined geographical spaces that are designated and managed to achieve the conservation of marine ecosystems from a long-term perspective [14]. MPAs have been recognized as one of the best tools for the conservation of marine ecosystems as they are intended to limit anthropogenic activities [15] [16] [17]. However, by establishing an MPA, there is no assurance that it will inherently result in positive impacts on the environment. Currently, many scientists still argue about their actual effectiveness, considering the conservation goals they aim to achieve [18] [19].

Since MPAs are not physical barriers, the ecosystem existing within their boundaries could still be exposed to pollution, temperature increase, ocean acidification, and other indirect threats. In addition, the size of the MPA could be insufficient to meet its conservation purpose [20]. Furthermore, there could be a lack of compliance and/or enforcement of the MPA regulations, resulting in a legally recognized MPA that is actually not being managed. However, MPAs have been shown in some instances to reduce human threats to marine ecosystems and have been proven to increase biodiversity, biomass, and ecosystem health if they are adequately designated, and well managed [16] [21]. To date, only $2.2 \%$ of the world's oceans are protected [22] and only about $33 \%$ of these MPAs might be truly effective, defined as "the degree to which management actions are achieving the goals and objectives of the protected area" [23].

Currently, no standard method for evaluating effectiveness has been recognized, and thus measurements vary among MPAs. Additionally, given their place-based nature, the effectiveness of MPAs needs to be evaluated on a case-by-case study to determine if management improvements or other conservation measures are 
being achieved or indeed, even necessary for that particular area [24]. Given the socio-economic consequences associated with declaring areas of ocean protected in order to achieve conservation objectives, this paper contributes to the growing global need to assess MPAs as an effective management tool. The purpose of this study is to develop an adapted MPA evaluation framework to monitor MPA effectiveness and to test the framework using the Tobago Cays Marine Park (TCMP), located in St. Vincent and the Grenadines (SVG) in the eastern Caribbean. Due to the limited information existing about the current performance of the TCMP, this assessment provides needed insight on the effect that this MPA is having on the marine ecosystem, as well as its overall management performance.

This study aims to develop the evaluation framework based on a modification to the scorecard system developed by the World Bank [25] [26] and incorporating MPA performance indicators recommended by Pomeroy et al. [23]. Moreover, in order to evaluate the TCMP as a functioning MPA, this study then assesses its performance regarding the different parts of the management process using the modified evaluation framework as well as compares the results obtained in 2016 with a partially conducted evaluation in 2007. In order to provide more information of the TCMP performance, this desktop assessment is supplemented with field research designed to assess the outcome of the management measures in place at TCMP by examining the effects of this MPA on the abundance of an economically important species, Lobatus gigas, commonly referred to as the queen conch. Finally, this study aims to provide recommendations on additional indicators for improving the monitoring and evaluation of the TCMP to achieve its stated goals, as well as recommendations to improve the management effectiveness of the Park and provide lessons for other MPAs.

\section{Study Area}

SVG is located in the West Indies (southeastern Caribbean Sea). Comprised of 32 islands, the country has some $390 \mathrm{~km}^{2}$ of land, and $406 \mathrm{~km}$ of coastline (Figure 1). As with most Caribbean islands, tourism is an important contributor to the country's gross domestic product (GDP) and foreign exchange earnings [27] [28].

The TCMP, established in 1986, is a $51.8 \mathrm{~km}^{2}$ MPA located in the southern territory of SVG. It was originally proposed to facilitate increasing tourism in the country as the area was identified as the most popular destination for marine tourism in the region [29] [30]. The MPA comprises the east side of Mayreau Island, five uninhabited Cays (Petit Bateau, Petit Rameau, Baradel, Jamesby, and Petit Tabac), and the surrounding marine area [27] [28] [29] (Figure 2). According to the SVG Census Office, in 2012 Mayreau had an estimated population of 271 inhabitants [31].

The MPA comprises many types of coral reefs, sea grass beds, and patches of endangered mangrove ecosystems. In addition, it is a nursery area for conch, lobster, fish, and green turtles. Furthermore, the Tobago Cays present the largest 

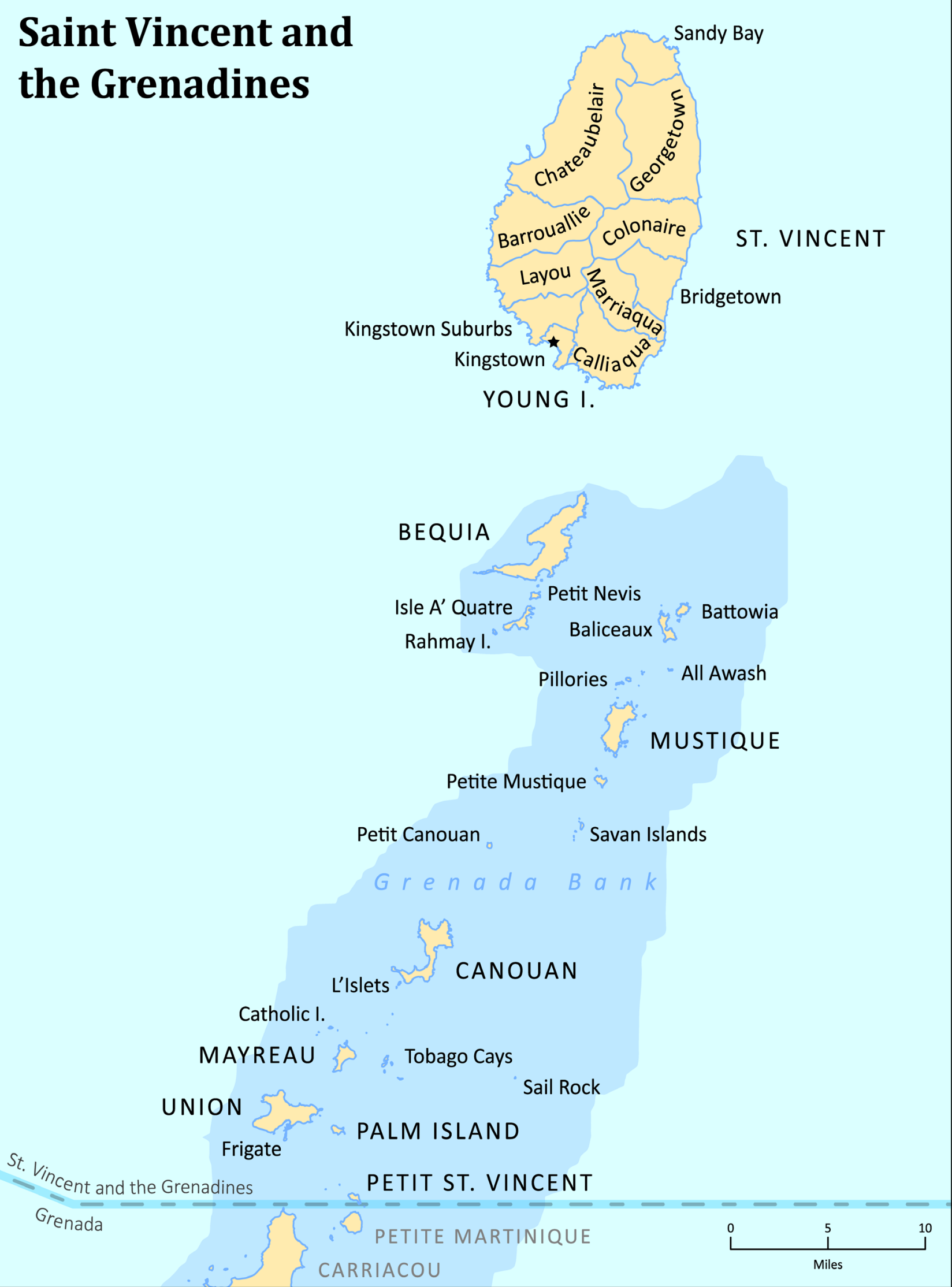

Figure 1. Map showing location of St. Vincent and the Grenadines in the south-east Caribbean (Source: AlyDeGraffOllivierre). 


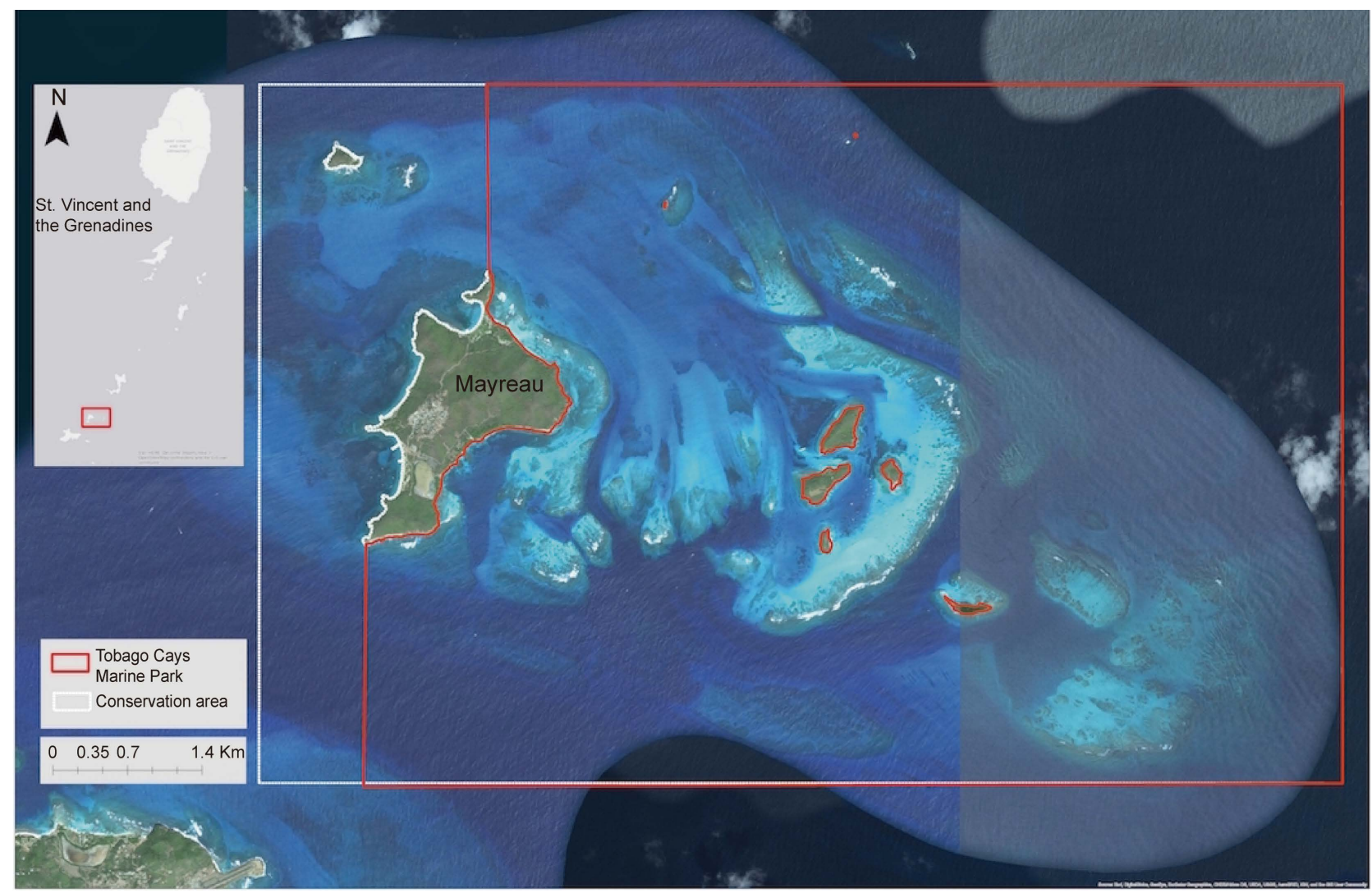

Figure 2. Satellite map of the TCMP.

seagrass bed of the country [27] [29] [30]. This area is regulated under the SVG National Parks Authority, and managed by the TCMP as a statutory body. In addition, regulations and laws are implemented by the TCMP [29].

According to the United Nations Environment Program (UNEP) and the TCMP Management Plan of 2007, the goals of TCMP can be summarized as: (1) Enhance conservation and management of biological diversity of the area; (2) Sustain economic benefits from the use of existing natural resources; (3) Increase public awareness of environmental issues and create a strong resources management system; and (4) Contribute to public education to increase engagement and achieve the objectives of the management plan [29] [31]. To date, the effectiveness of the TCMP as an MPA has not been conducted although a partial assessment of the management process was undertaken in 2007 [29].

\section{The Modified MPA Effectiveness Framework}

\subsection{Adapted Scorecard for Measuring MPA Effectiveness}

The scorecard developed by the World Bank in 2004 for assessing MPA effectiveness originally included 34 questions distributed among six categories, namely context, planning, inputs, process, output, and outcome [25]. The scorecard was adapted by supplementing the questions identified for the "process" category with 36 indicators developed by Pomeroy et al. [23], focusing on the identification and evaluation of the goals of the MPA as well as on communi- 
cating the improvements needed in the management of the evaluated MPA (Appendix 1). This modification of the original scorecard was viewed as improving the evaluation of the effectiveness of the MPA by acquiring more monitoring details and to guide the selection of the best indicators to be measured according to the MPA's goals. To achieve this, questions in the Process category were adapted. Question 19 of the original scorecard was divided into three separate questions to address specific biophysical, socioeconomic, and governance indicators (Question 19, 23 and 25) and the relevant indicators from Pomeroy et al. [23] for each of these were then assigned as illustrated in Questions 20, 24 and 26 (Appendix 1). Lastly, to conduct a more comprehensive evaluation of the monitoring activities undertaken within the MPA, the adapted scorecard was modified to also incorporate questions on the different spatial and temporal scales being measured as recommended by Stelzenmuller and Pinnegar in 2011 [26], as well as the frequency for monitoring biophysical indicators (Questions 21 and 22, Appendix 1).

To obtain a preliminary assessment of the TCMP using the adapted evaluation framework, responses to the questions were obtained based on a literature review of key TCMP's management and monitoring documents (e.g. the TCMP management plan, as well as previous assessments and documents describing the area and its management) and in person experience in the area while conducting research on the TCMP [27] [29] [32] [33] [34]. The majority of the indicators were scored on a scale of 0 to 3 (three being scored on a scale of 0 to 2 due to the nature of the questions), with the opportunity for bonus points to be awarded. Effectiveness was calculated based on percent of maximum allowable score obtainable where $0 \%$ - 29\% was deemed "deficient", 30\% - 49\% was "limited", 50\% - $69 \%$ was "fair", $70 \%-79 \%$ was "good" and more than $80 \%$ was considered to be "excellent".

In addition to the assessment of the TCMP performance in 2016 using the modified scorecard comprised of both the original and supplemental questions, a comparative assessment was undertaken of the results obtained in 2016 using the adapted scorecard with the 2007 assessment using the original scorecard [25]. This comparison allowed for improvements in the effectiveness of the TCMP over a ten-year period to be determined as well as highlighted the additional management information gleaned from a more in-depth monitoring scorecard when assessing MPA effectiveness in 2016.

\subsection{Queen Conch Density Surveys to Measure MPA Effectiveness}

As noted by scholars and practitioners in the field of MPA management, the ultimate objective of MPAs is to enhance marine conservation. To determine whether this outcome has been achieved by the TCMP, the desktop assessment using the adapted scorecard was supplemented with in situ fieldwork aimed at assessing queen conch abundance and density inside and outside of the Park. Queen conch is a very important resource (environmentally, economically, and culturally) in SVG, as well as in most Caribbean countries. Current management 
regulations for queen conch in the Grenadines include size limits and protected fishing areas such as the TCMP [35]. However, the TCMP has had many management problems since its creation, and the effect that this MPA might be having in regards to queen conch conservation is not clear. In order to measure the effect of the TCMP on conch abundance to determine its contribution to conch conservation, a stratified random sampling approach was conducted. Underwater surveys were conducted outside (six surveys) and inside the MPA (six surveys). The sites were identified after considering the bathymetry of the area, information on conch distribution provided by the fishing community, and suitable habitats where conch could be found (Figure 3). Each underwater survey consisted on four belt transects of $30 \mathrm{~m}$ length and $2 \mathrm{~m}$ wide (north, west, south, and east of a deployed buoy on the coordinates of each site), where data on conch abundance was gathered.

The total density of conch in the study area was obtained by calculating the total area surveyed and the amount of conch encountered within that area. The total area sampled in the study area was $5,760 \mathrm{~m}^{2}$ (0.576 hectares), with an equal area surveyed inside and outside the TCMP. Conch density inside the TCMP was obtained using the total area sampled within its boundaries ( 0.288 hectares). The same procedure was used to obtain conch density in the Union area outside the MPA. Conch density found inside the Park was compared to conch density

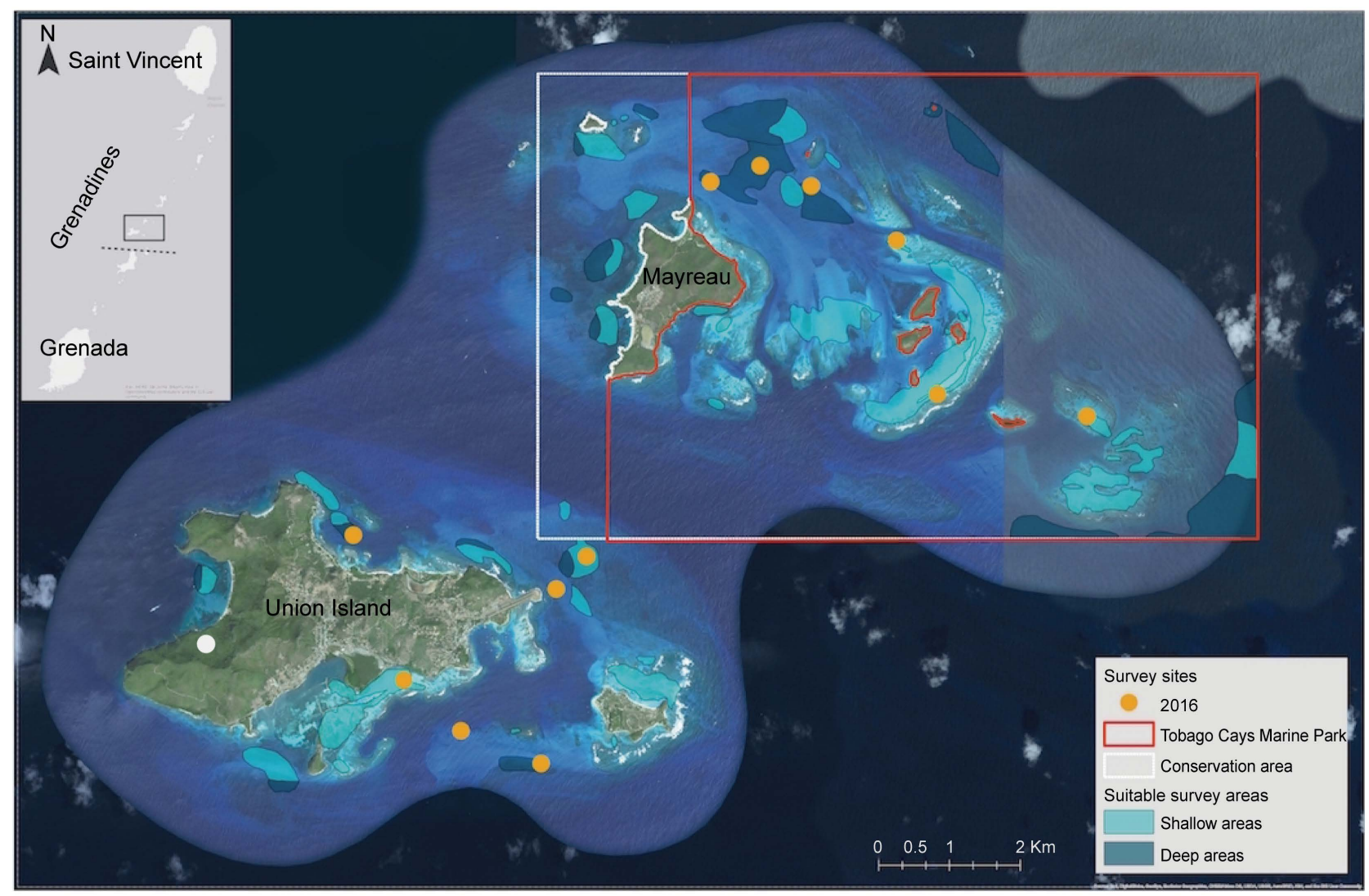

Figure 3. Survey sites map. Light blue areas indicate shallow areas (0 - 10 meters), and dark blue areas indicate deeper areas (10 20 meters). Survey sites are marked with an orange circle. 
found outside, in total and by maturity stage (juveniles and adults). Conch with lip thickness less than $4 \mathrm{~mm}$ and shell length less than $20 \mathrm{~cm}$ were considered juveniles [36] [37]. Using the statistical software SPSS, Shapiro-Wilk normality tests were used to obtain information on the distribution of the data. Due to the reduced sample size and the distribution pattern of this species, the data did not follow a normal distribution for any of the conducted tests. Therefore, nonparametric analyses were conducted. Specifically, the Wilcoxon signed-rank test was used to conduct pairwise comparisons among groups. The TCMP Rangers provided boat access to the survey sites as well as participated in the surveys.

\section{Results}

\subsection{TCMP Effectiveness Scores Using the Adapted Scorecard}

Using available documentation on the TCMP and in person observations, all questions included in the adapted scorecard (Appendix 1) could be adequately addressed except for four of the Outcomes section questions due to lack of reliable, available information. Results showed that the TCMP scored a ranking equating to "fairly" effective in the Context, Inputs, and Outputs categories (61\% - 62\%) and a ranking of "limited" effectiveness in terms of the Process and Planning categories $(33 \%-36 \%)$. The scoring for the Park for indicators assessing Outcomes indicated its effectiveness for this category could be termed "deficient", having received a score of only $22 \%$. The overall assessment of TCMP effectiveness could be considered "limited", based on a score 39\% for the six categories included in the adapted scorecard (Table 1).

The urgent need for improvement in the performance of the TCMP, as identified using the modified scorecard is highlighted in Figure 4. While there is room for improvement in the Context, Inputs and Output categories, having all been assigned a ranking of "fair", attention should be prioritized to address issues associated with Planning and Process which have been assigned a ranking of "deficient". Given improvements in these categories, one can expect better scores for the expected Outcomes over time.

Table 1. Summary results of TCMP effectiveness in 2016 using the adapted scorecard.

\begin{tabular}{|c|c|c|c|c|}
\hline Scorecard section & $\begin{array}{l}\text { Maximum } \\
\text { score }\end{array}$ & $\begin{array}{l}\text { TCMP score } \\
2016\end{array}$ & $\begin{array}{c}\text { Effectiveness } \\
\text { percentage } 2016\end{array}$ & $\begin{array}{c}\text { Qualitative } \\
\text { ranking }^{*}\end{array}$ \\
\hline Context (7 questions) & 26 & 16 & $62 \%$ & Fair \\
\hline Planning (2 questions) & 14 & 5 & $36 \%$ & Limited \\
\hline Inputs ( 3 questions) & 13 & 8 & $62 \%$ & Fair \\
\hline Process (adapted) (14 questions) & 123 & 40 & $33 \%$ & Limited \\
\hline Outputs (8 questions) & 33 & 20 & $61 \%$ & Fair \\
\hline Outcomes (7 questions) & 27 & 4 & $15 \%$ & Deficient \\
\hline Overall TCMP performance & 236 & 93 & $39 \%$ & Limited \\
\hline
\end{tabular}

${ }^{*}$ Qualitative assessment of the rankings equate to $0 \%-29 \%$ as deficient; $30 \%-49 \%$ as limited; $50 \%-69 \%$ as fair; $70 \%-79 \%$ as good and over $80 \%$ as excellent. 


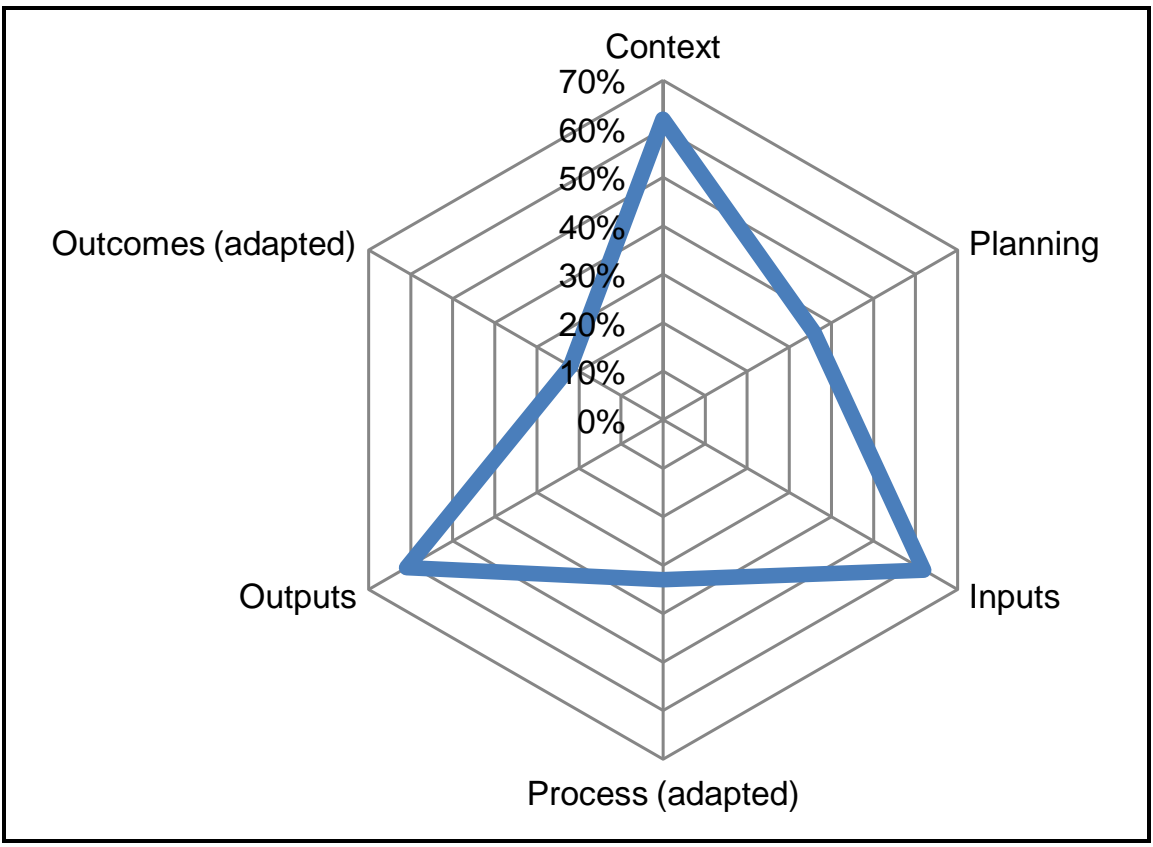

Figure 4. TCMP effectiveness by category in 2016 using the adapted scorecard.

\subsection{Evaluating Effectiveness over the Period 2007 to 2016}

This analysis examined the results obtained using the original scorecard for 2007 and the adapted scorecard for 2016 where additional questions were added to the Process category. To highlight the difference in the scoring for Process indicators using the different scorecards, the scoring for this category are shown using those questions asked in the original scorecard and the supplemental questions added to create the modified scorecard.

When compared to the results of 2007, the assessment of effectiveness in 2016 relating to Context, Inputs, and Outputs showed considerable improvement (Figure 5). This was attributed to better control of human activities in the Park, the start of the process to include the TCMP into a larger coastal management plan, and the availability of more information to manage the area (Table 2). In addition, it seemed that the staff and budget had slightly improved in 2016 over 2007. However, stakeholder engagement and participation decreased in the ensuing decade. The assessment conducted in 2007 provided no information on measuring indicators addressing Outputs. In contrast, the 2016 Output scores were relatively high due to the improvement in the MPA legal status, management, enforcement, boundary demarcation, resource inventory, existence of moorings, existence of visitor facilities, fees that support the management of the MPA, etc. (Table 2).

Regarding the Planning category, even though there has been an agreement on the goals for the MPA and an increased level of implementation of the management plan since 2007, the scores assigned for both years were the same. For 2016, these higher scores were offset by the decrease in stakeholder participation and the inclusion of socioeconomic issues. However, as shown in Table 3, both assessments obtained similar scores for different reasons. 


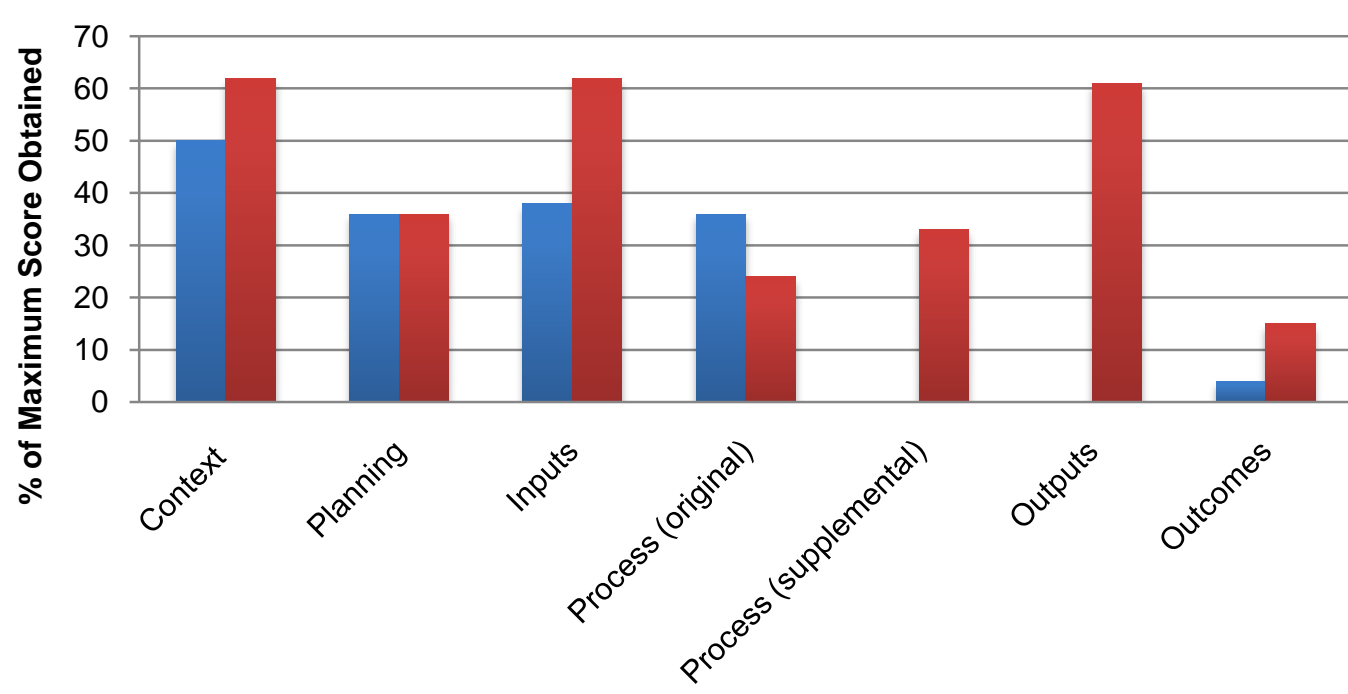

\section{Scorecard Categories}

Figure 5. Scores obtained in 2007 and 2016 regarding TCMP effectiveness using the original scorecard for 2007 and the adapted scorecard for 2016 .

Table 2. Summary results of TCMP effectiveness in 2016 using the adapted scorecard.

\section{Questions}

Scored on a scale of $0,1,2$, or 3 (except Q.29, 30 and

31 scored from 0 to 2 ) plus potential for bonus points

(See Appendix 1 for scoring criteria).

Context: Assessing threats and the policy environment

Q1. Legal Status: Does the MPA have legal status?

Bonus point: The MPA has received national or/and international recognition for its importance.

$\begin{array}{lll}\text { TCMP } & \text { TCMP } & \\ \text { score } & \text { score } & \text { Comments } \\ 2007 & 2016 & \end{array}$

Q2. MPA regulations: Are unsustainable human activities controlled?

Q3. Law enforcement: Can staff sufficiently enforce regulations?

Bonus point: There are additional sources of control (e.g., volunteers, national services, local communities).

Bonus point: Infractions are regularly prosecuted; fines levied.

Q4. MPA boundaries: Are boundaries known to staff and stakeholders?

Q5. Integration of the MPA in a larger coastal management plan: Is the MPA part of a larger coastal management plan?

Bonus Point. The MPA is part of a network of MPAs, which collectively sustain larger marine ecosystem functions.

Bonus Point. The MPA is part of a network of MPAs, which collectively represent the range of bio-geographic variation in a marine eco-region.
Q1. The MPA was designated in 1987 under the Fisheries regulations; it was legally recognized in 1997. This MPA has been nationally recognized due to its ecologic significance and touristic importance.

Q2. Activities, such as illegal fishing, have been controlled and reduced but others such as nutrient pollution from yachts remain unaddressed.

Q3. There are major deficiencies in staff capacity/resources to enforce MPA legislation and regulations, e.g. MPA staff cannot fine vessels anchoring in undesignated areas. The National Parks Authority, and the NGO, Sustainable Grenadines Inc. (SusGren) assist with management-related activities.

Q4. The boundaries of the MPA are not properly demarcated. In 2016 management staff and other stakeholders were aware of them while in 2007, only staff was aware.

Q5. This MPA is now part of the Climate-Resilient Eastern Caribbean Marine Managed Areas Network (ECMMAN) Project, following discussions in 2007. This project involves marine managed areas from six different Caribbean countries. However, not all areas included in the Network within SVG have been implemented. Information available in 2007 existed but was insufficient to support planning. 


\section{Continued}

\section{Questions}

Scored on a scale of $0,1,2$, or 3 (except Q.29, 30 and

31 scored from 0 to 2 ) plus potential for bonus points (See Appendix 1 for scoring criteria).

Q6. Resource inventory: Is there enough

information to manage the area?

Q7. Stakeholder awareness and concern:

Are stakeholders aware and concerned about

marine resource conditions and threats?

Total score obtained out of a possible

maximum of 26

Inputs: Assessing resources needed for management

Q10. Research: Is there a program of management-

oriented survey and research work?

Bonus Point: Carrying capacity studies have been

conducted to determine sustainable use levels.

Q11. Staff numbers: Are there enough people employed

to manage the MPA?

Bonus Point: There is additional support from volunteer

programs, local communities, etc.

Q12. Current Budget: Is the current budget sufficient?

Bonus Point: There is a secure budget for the MPA and

its management needs on a multi-year basis.

Bonus Point: The budget is not entirely dependent on

government funding.

Total score obtained out of a possible maximum of 13

Q27. Context indicators: 2 Bonus Points each

Has the legal status improved?

Have regulations improved?

Has law enforcement improved?

Has boundary demarcation improved?

Is the MPA part of Integrated Coastal Management?

Has the resource inventory improved?

Has stakeholder awareness and concern improved?

\section{Q28. Product and Services:}

Bonus point: Are signs available and have they

been installed?

2 Bonus Points. Have moorings been installed?

Bonus point: Is there educational material available?

Q29. Stakeholder engagement: Are mechanisms

available to ensure stakeholder participation?

(Maximum score $=2$ )

Q30. Environmental education for stakeholders:

Have education activities been developed for

stakeholders? (Maximum score $=2$ )

Q31. Management activities: Have the most

critical management activities been improved

to address threats? (Maximum score 2)

Q32. Visitor facilities: Does the MPA have

adequate visitor facilities?

Q33. Fees: If fees are applied, do they help

MPA management?

Q34. Staff training: Is the staff adequately trained?

Total score obtained out of a possible

maximum of 33

\section{TCMP TCMP \\ score score Comments \\ $2007 \quad 2016$}

12

Q6. Relevant information for management has increased in 2016 but monitoring is ad hoc.

Q7. Approximately $50 \%-75 \%$ of stakeholders are aware or concerned about the marine resource conditions and threats due to management capacity and development.

$13 \quad 16$

1

Q10. Ad hoc research activities mainly conducted by external entities; limited data and availability.

\section{$2 \quad$ Q11. Staff number appears to be adequate but Rangers} focus primarily on user fees for yachts and mooring maintenance.

$\begin{array}{lll}1 & 2 & \begin{array}{l}\text { Q12. Government provides approximately 25\% of } \\ \text { operating budget of some } \$ 225,000 \text { with remainder } \\ \text { from user fees and fines. Ad hoc research grants } \\ \text { from external donors are being granted. }\end{array}\end{array}$

8 from external donors are being granted.

ns, and delivery of products and services

Q27. Legal status, regulations, law enforcement, and boundary demarcation have all improved since the MPA was established. In 1999 the presence of fishermen was reported on a daily basis on the area, fishing conch and lobster, while currently these practices have been much reduced. The resources inventory has been 2 updated due to research conducted in the area regarding species abundance.

Q28. There are a high number of moorings with new ones being installed.

2

Q29. It seems that no mechanisms for stakeholder

0 participation in decision-making currently exist at the TCMP.

Q30. It seems that no education activities for stakeholders are being currently conducted.

Q31. Control of illegal fishing has improved since this measure was reported in 1999 but it still occurs within the MPA and tourism activities need to be better managed. Q32. There are some facilities such as an interpretation center, moorings, and a small area for visitors in one of the Cays. Currently, there is a lack of washroom facilities. Q33. Fees are applied to all visitors and are used for management of the MPA.

Q34. Training seems to be developed in a non-consistent basis, and needs to be improved.

20


Table 3. 2007 and 2016 comparison of TCMP Planning scores.

\begin{tabular}{|c|c|c|c|}
\hline $\begin{array}{l}\text { Questions } \\
\text { Scored on a scale of } 0,1,2 \text {, or } 3 \text { (except Q.29, } 30 \text { and } \\
31 \text { scored from } 0 \text { to 2) plus potential for bonus points } \\
\text { (See Appendix } 1 \text { for scoring criteria). }\end{array}$ & $\begin{array}{l}\text { TCMP } \\
\text { score } \\
2007\end{array}$ & $\begin{array}{l}\text { TCMP } \\
\text { score } \\
2016\end{array}$ & Comments \\
\hline \multicolumn{4}{|l|}{ Planning: Assessing MPA design and planning } \\
\hline Q8. MPA objectives: Have objectives been agreed? & 0 & 2 & $\begin{array}{l}\text { Q8. MPA objectives seemed to have been agreed to but } \\
\text { they are not being fully met in } 2016 \text {. The management } \\
\text { plan was created in } 2007 \text { but it had not been fully } \\
\text { implemented yet in } 2016 \text {. }\end{array}$ \\
\hline $\begin{array}{l}\text { Q9. Management Plan: Is there a management plan, } \\
\text { and is it being implemented? }\end{array}$ & 1 & 2 & \multirow{5}{*}{$\begin{array}{l}\text { Q9. During the creation of the management plan, } \\
\text { stakeholders' feedback was considered at consultation } \\
\text { workshops held in Union Island and Kingstown. } \\
\text { However, currently it appears that stakeholder } \\
\text { participation in decision-making and management } \\
\text { is very limited or inexistent. }\end{array}$} \\
\hline $\begin{array}{l}\text { Bonus Points: The planning process allows adequate } \\
\text { opportunity for key stakeholders to influence the } \\
\text { management plan; }\end{array}$ & 1 & .1 & \\
\hline $\begin{array}{l}\text { Stakeholder representation includes various ethnic, } \\
\text { religious, and user groups as well as representation } \\
\text { from both genders; }\end{array}$ & 1 & & \\
\hline $\begin{array}{l}\text { The socioeconomic impacts of decisions are taken } \\
\text { into account; }\end{array}$ & 1 & & \\
\hline $\begin{array}{l}\text { The local culture, including traditional practices, } \\
\text { social systems, cultural features, historic sites and } \\
\text { monuments, are considered in the planning process. }\end{array}$ & 1 & & \\
\hline Total score obtained out of a possible maximum of 14 & 5 & 5 & \\
\hline
\end{tabular}

With regard to the assessment of Outcome indicators in 2007, only one subquestion was addressed, specifying that resource conflict had been reduced. The 2016 scores for Outcomes, while higher than that obtained in 2007, scored only a $15 \%$ effectiveness ranking. This was due to management objectives and threats had not been fully addressed, overall resource conditions not improving, and lack of current information to score the community welfare, environmental awareness and stakeholder satisfaction with the outcomes of compliance and management of this MPA (Table 4).

Finally, in the Process category, the score for 2016 was lower than in 2007 when using the original scorecard only (Figure 5). This was the result of the apparent lack of communication between managers and stakeholders, and a reduction in stakeholder participation. Using the supplemental questions as a measure of effectiveness in 2016 in the adapted scorecard, the Process section obtained a higher score due to the evaluation of information available for specific monitoring indicators in the modified framework (Table 5).

\subsection{Selecting Indicators to Assess Achievement of TCMP's Goals}

Based on the four goals identified for the TCMP and the indicators highlighted in the adapted framework, 20 indicators in total (five for each of the four goals) were identified as important for future assessment of progress towards achieving the goals. Of these indicators, 17 were part of the set proposed by Pomeroy et al. 
Table 4. 2007 and 2016 comparison of TCMP Outcome scores.

\section{Questions}

Scored on a scale of $0,1,2$, or 3 (except Q.29, 30 and 31 scored from 0 to 2 ) plus potential for bonus points (See Appendix 1 for scoring criteria).
TCMP TCMP

score score Comments

20072016

Outcomes: Assessing changes in environmental status and behavior as a result of management programs and actions

Q35. Objectives: Have MPA objectives been addressed?

Q36. Threats: Have threats been reduced?

Q37. Resource conditions:

Have resource conditions improved?
Q35. Currently, only Goal 2 focusing on economic

1 benefits has been addressed by using the fee system for visitors of the Park.

Q38. Community welfare: Has community welfare improved?

Bonus point: MPA management is compatible with the local culture, including traditional practices, relationships, social systems, cultural features, historic sites, and monuments linked to marine resources and uses.

Bonus point: Resource use conflicts have been reduced.

Bonus point. Benefits from the MPA are equitably distributed.

Q36. Illegal fishing has been reduced as well as anchoring damage.

Q37. Abundance of herbivorous and commercial fish has increased but coral cover has decreased as well as the size of commercial fish.

Bonus point: The nonmonetary benefits of the marine resources to society have been maintained or enhanced.

Q39. Environmental awareness: Has community environmental awareness improved?

Q40. Compliance: Are users complying with MPA regulations?
Q38. Tourism has positively impacted the local community economically but there is no data to track if community welfare has improved as a result. Conflicts arising from the introduction of the Park boundaries initially decreased in 2007 with no subsequent change in 2016.

Q39. While it would appear the environmental awareness has increased over time, there is no information available to attribute this to the TCMP, especially since education and awareness arising efforts by the Park have decreased over time.

Q40. Regarding compliance improvement, no information is currently available although this could be tracked using number of infractions cited. However, most effort on compliance is dedicated to touristic usage of moorings and user fees.

Q41. Stakeholder satisfaction: Are the stakeholders satisfied with the process and outputs of the MPA?

Bonus point: Stakeholders feel that they are able to effectively participate in management decisions.

Q41. Stakeholders in the community shared their dissatisfaction with the MPA and its regulations anecdotally but a specific assessment in terms of percentage has not been undertaken.

Bonus point: Stakeholders feel that they are adequately represented in the MPA decision-making processes.

Total score obtained out of a possible maximum of 27 
Table 5. 2007 and 2016 comparison of TCMP Process scores.

Questions

Scored on a scale of $0,1,2$, or 3 (except Q.29, 30 and 31 scored from 0 to 2 ) plus potential for bonus points TCMP TCMP

score score Comments

(See Appendix 1 for scoring criteria).

$2007 \quad 2016$

Process: Assessing how management decisions and actions are made

Q13. Education and awareness program: Is there a planned education program?

Q14. Communication between stakeholders and managers: Is there communication between stakeholders and managers?

10

Bonus point: There is some communication with other MPA managers. 1
Q13. Education and awareness activities are not frequently conducted and are mostly developed by external organizations.

Q15. Stakeholders' involvement and participation: Do stakeholders have meaningful input to

management decisions?

Q15. As with communication, actual stakeholder involvement, including local residents, in the management process has decreased over time.

Bonus Point: There are clear financial contributors

Q14. Current communication between stakeholders and managers has decreased over time. External organizations (e.g. SusGren and The Nature Conservancy-TNC) help to facilitate some communication with the managers of other MPAs that are part of the Grenadines Network of MPAs.

or agreements between MPA and tourism operators

to recover MPA resources rents for local benefits.

Q16. Indigenous people: Do indigenous and traditional people resident or regularly using the MPA have input to management decisions?

10

Q17. Staff training: Is there enough training for staff? $\quad 1$

Q17. Staff has been trained in patrolling the area mostly with the purpose of fees collection. Staff seems to be also trained, mostly by the support of external organizations in other activities such as monitoring or first aid. However, training is low considering the needs and objectives of the MPA outlined in its management plan.

Q18. Equipment is available for patrolling but resources

Q18. Equipment: Is the site adequately equipped?

1

for maintenance can be improved. Diving equipment appears to be mostly unused and in need of maintenance due to lack of monitoring activities by Park staff.

Q19. Monitoring and evaluation: Are biophysical indicators monitored and evaluated?

Bonus Point: The MPA participates as a site in national or international environmental monitoring programs.

Bonus Point: There is an Emergency Response Capability in place to mitigate impacts.
Q19. The measurement of biophysical indicators is not frequently or continuously carried out. When gathered, it is usually due to the efforts of external organizations such as SusGren, TNC, or others. This MPA participates in the Atlantic and Gulf Rapid Reef Assessment (AGRRA) (http://www.agrra.org) Program, and therefore at least four indicators have been measured in multiple research campaigns: coral cover, fleshy macroalgae cover, abundance of herbivorous fish, and abundance of commercial fish.

Original scorecard: total score obtained out of a possible maximum of 25 


\section{Continued}

\section{Questions}

Scored on a scale of $0,1,2$, or 3 (except Q.29, 30 and

31 scored from 0 to 2 ) plus potential for bonus points (See Appendix 1 for scoring criteria).

Q20. Biophysical parameters: 2 Bonus Points each

Focal species abundance

Composition and community structure

score

$2007 \quad 2016$
Comments
Food web integrity

Habitat distribution and complexity

Focal species population structure

Recruitment success within the community

Fishing effort

Water quality

Area showing signs of recovery

Area under no or reduced human impact

Q21. How are the biophysical indicators being

measured/monitored? (Maximum score $=2$ )

Temporally

Spatially

Q22. How frequently are the biophysical indicators

being measured?

Bonus Point: Some parameters are measured more

than once every year

Q23. Monitoring and evaluation: Are socioeconomic

indicators monitored and evaluated?

Q24. Socioeconomic Parameters: 2 Bonus Points each

Local marine resource use patterns

Local values and beliefs regarding the marine resources

Level of understanding of human impact on resources

Perceptions of seafood availability

Perceptions of local resource harvest

Perceptions of nonmarket and nonuse value

Material lifestyle

Quality of human health

Household income distribution by source

Household occupational structure

Community infrastructure and business

Number and nature of markets

Stakeholder knowledge of natural history
Q21. Research has only been conducted after the implementation of the MPA, and mostly inside the MPA boundaries so comparisons on the impact of the Park is limited.

Q22. Frequency of monitoring depends on external organizations and funding. However, there are few activities being developed on a yearly basis such as turtle monitoring and seabird monitoring. Q23. Some socio-economic information was gathered ten years ago but current information is very limited. Q24. Information regarding the use of the marine area has been gathered, as well as regarding infrastructure existing on the area. In addition, employment and unemployment rate information is also available. Information on the different fishing gear used by fishermen, the fishing fleet, and the landed value from 1999-2006 had also been gathered previously. Furthermore, data on household income and 2 stakeholders' level of education was also gathered in a previous research. Finally, information regarding concerns of the area was collected in a previous survey, as well as perception information of the importance of the reefs at the TCMP. All data collection efforts were undertaken by entities external to the TCMP.

Distribution of formal knowledge to community

Percentage of stakeholder group in leadership positions

Changes in conditions of ancestral and historical sites,

features, and/or monuments 


\section{Continued}

\section{Questions}

Scored on a scale of $0,1,2$, or 3 (except Q.29, 30 and 31

scored from 0 to 2 ) plus potential for bonus points

(See Appendix 1 for scoring criteria).

Q25. Monitoring and evaluation: Are governance

indicators monitored and evaluated?

Q26. Governance Parameters: 2 Bonus Points each

Level of resource conflict

Existence of a decision-making and management body

Existence and adoption of a management plan

Local understanding of MPA and rules and regulations

Existence and adequacy of enabling legislation

Availability and allocation of MPA administrative resources

Existence and application of scientific research and input

Existence and activity level of community organization(s)

Degree of interaction between managers and stakeholders

Proportion of stakeholders trained in sustainable use

Level of training provided to stakeholders in participation

Level of stakeholders participation and satisfaction in

management process and activities

Level of stakeholder involvement in surveillance,

monitoring, and enforcement

Clearly defined enforcement procedures

Enforcement coverage

Degree of information dissemination to encourage

stakeholder compliance

$\begin{array}{lll}\text { TCMP } & \text { TCMP } & \\ \text { score } & \text { score } & \text { Comments } \\ 2007 & 2016 & \end{array}$

Q25. There seems to be limited information of governance indicators.
Q26. Information regarding stakeholders' recommendations and stakeholders' concerns was gathered in a previous research undertaken in 2007 when the management plan was developed and adopted. However, current information on these indicators is not available.

Supplemented questions in adapted scorecard for 2016 (Q20 - 26):

Total score obtained out of a possible maximum of 98

N/A $\quad 34$

Adapted scorecard for 2016: Total score obtained out of a possible maximum of 123 (original (25) + supplemental (98))

N/A $\quad 40$

(2005) [23], while three new ones (illegal activities rate; number of visitors; fees collected) were added by the authors in order to gain additional information regarding Goal 2, which focused on economic benefits (Table 6). In addition to their fit with the goals of the TCMP, criteria for selecting the indicators were based on availability of information (pre and post 2015) and feasibility to be monitored.

As noted from the assessment of available information, only six of the indicators have available information and of those, only one has current information, i.e. post 2015. However, it is worth noting that at least one indicator per goal has been tracked, allowing for limited progress on each of the goals to be assessed. The challenge for the TCMP is to obtain monitoring data on at least these six indicators on an ongoing basis and to increase the level of monitoring to more 
Table 6. Recommended indicators and availability of information to evaluate progress towards TCMP's conservation goals.

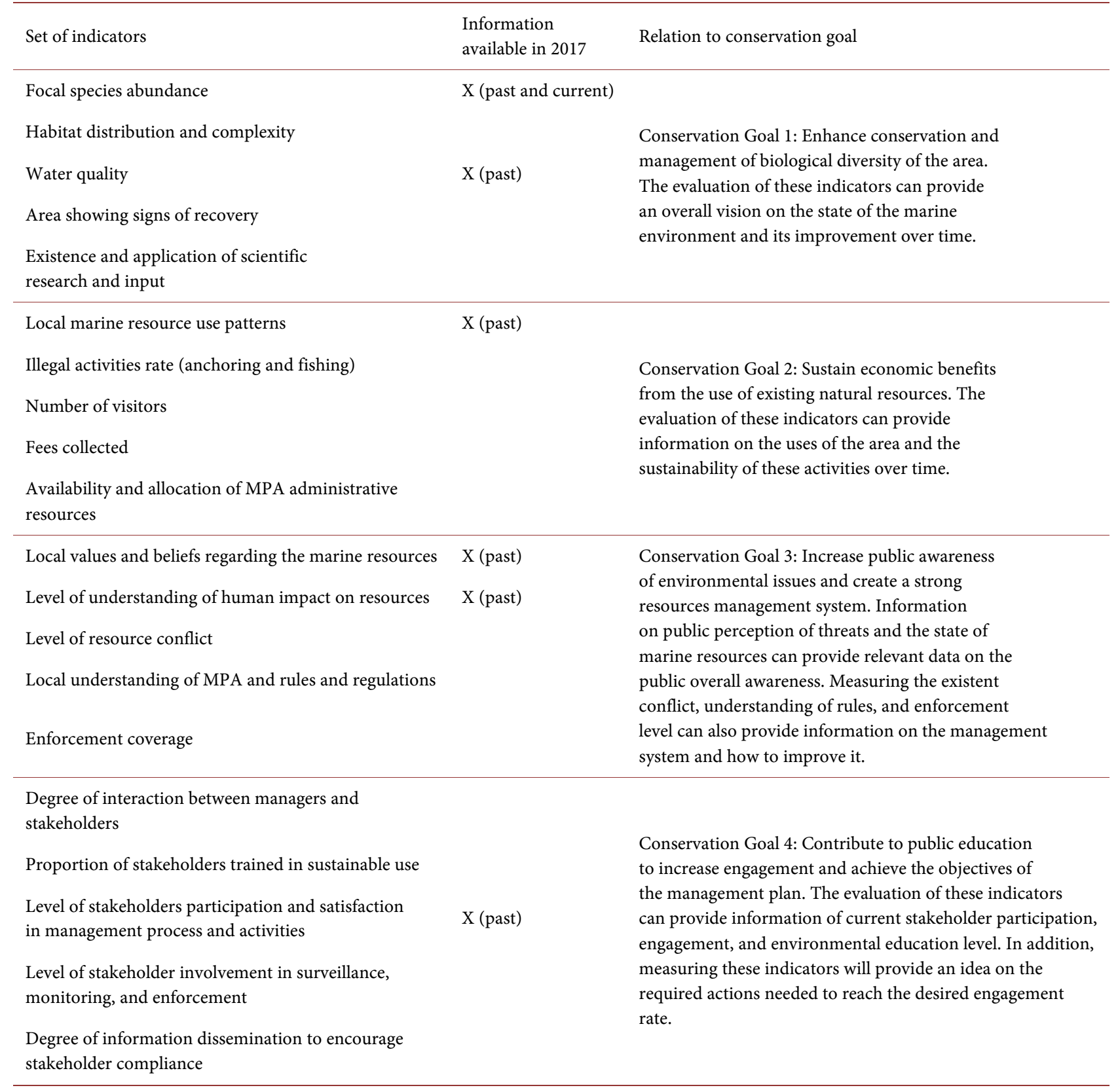

than the existing six indicators. As such, measuring progress towards Park goals would require a concerted monitoring effort on the part of Park staff and/or their partners. However, given the importance of tracking the achievement of Park goals to determine the effectiveness of the TCMP, a plan to put in place the mechanisms needed should be undertaken and implemented.

\subsection{A Preliminary Assessment of TCMP Effect on Conch Abundance and Density}

A total of 21 individuals were found during the surveys in 2016, 12 of them (57\%) were juveniles, while 9 of them (43\%) were adults. Conch density found in 
the study area was 36.4 individuals/ha in total, 20.8 juveniles/ha, and 15.6 adults/ha. Of the conch found, 16 individuals were encountered inside the TCMP (77\%), while only 5 (24\%) were encountered outside the TCMP. Interestingly, no adults were found outside the TCMP. Higher densities of conch were found in deeper areas (52.1 ind/ha in total), both for juveniles and adults. In shallow areas, the density was lower (20.8 ind/ha in total), and the proportion of adults and juveniles was equal (Table 7).

Multiple statistical tests were conducted to obtain further information regarding abundance in the study area. Results showed that in 2016 there was no significant difference between the total abundance of conch (Figure 6). Furthermore, the inclusion of the depth as a factor did not show any significant differences in regards to conch abundance in 2016.

Table 7. Abundance and density results for the 12 survey sites, in total and also by maturity level, protection level, and depth.

\begin{tabular}{|c|c|c|c|c|c|c|c|}
\hline & & \multicolumn{3}{|c|}{ Abundance (Individuals) } & \multicolumn{3}{|c|}{ Density (Ind/ha) } \\
\hline & & Juveniles & Adults & Total & Juveniles & Adults & Total \\
\hline \multirow{5}{*}{2016} & Study Area & 12 & 9 & 21 & 20.8 & 15.6 & 36.4 \\
\hline & Inside TCMP & 7 & 9 & 16 & 24.3 & 31.2 & 55.5 \\
\hline & Outside TCMP & 5 & 0 & 5 & 17.4 & 0 & 17.4 \\
\hline & Shallow & 3 & 3 & 6 & 10.4 & 10.4 & 20.8 \\
\hline & Deep & 9 & 6 & 15 & 31.2 & 20.8 & 52.0 \\
\hline
\end{tabular}

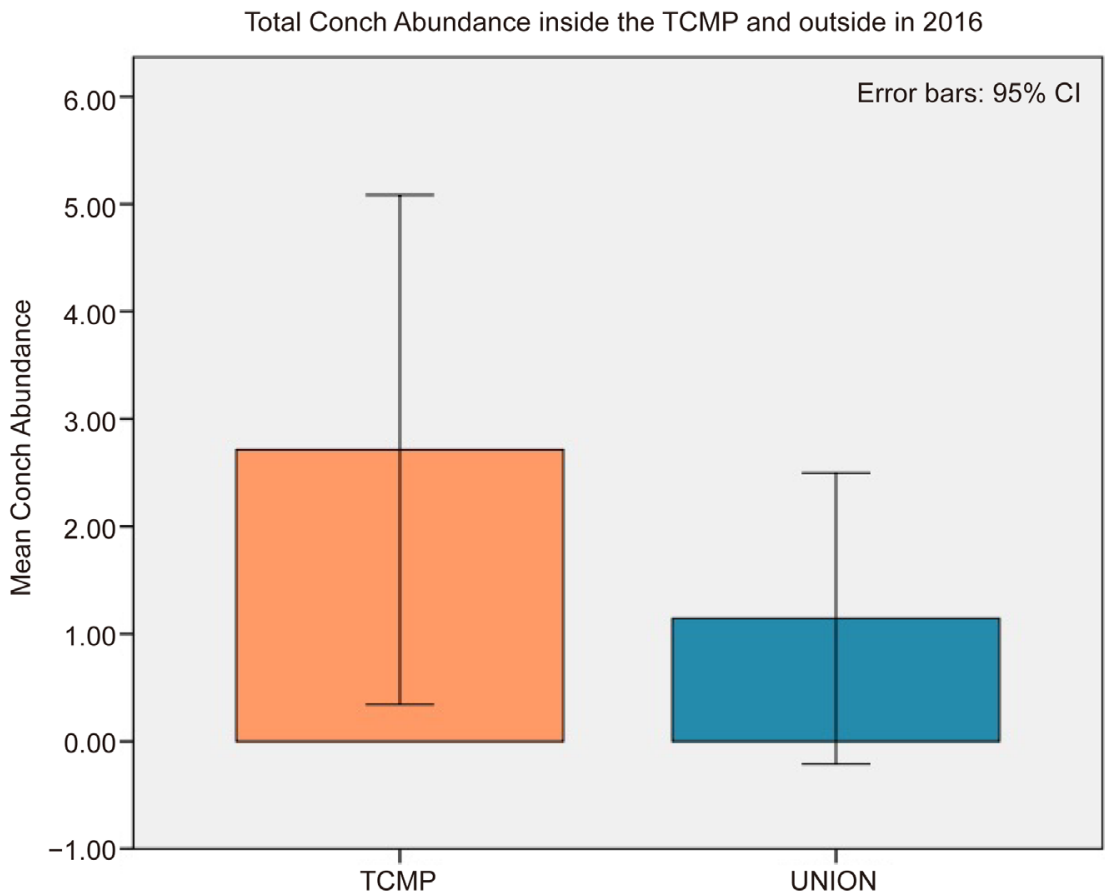

Figure 6. Mean values of total conch abundance inside and outside the TCMP in 2016. Error bars show 95\% confidence interval. Nonparametric statistic analysis (Wilcoxon test) showed no significant difference between these groups. The TCMP bar includes conch abundance inside the MPA, while UNION refers to conch abundance outside the MPA. 


\section{Discussion}

The focus of this paper has been to draw attention to the current status of the TCMP in meeting its stated goals, using a modified assessment framework. The results indicate areas in which the Park is doing an adequate job as well as challenges that need to be addressed. Overall, lack of dependable resources (funding and expertise) as well as lack of appropriate authority have been identified as significant factors limiting effective Park management. However, a key observation that bodes well for the TCMP is the support and interest of external organizations, both within SVG (e.g. SusGren) and more broadly (e.g. TNC, external researchers and the AGGRA Program to name a few). However, maximizing these opportunities to address shortcomings by the TCMP will require greater involvement of Park staff in communicating its specific needs and raising stakeholder awareness and involvement in contributing to meeting its stated goals. The following discussion on the scorecard results, the findings with respect to achievement of Park goals, and the preliminary assessment of the role of the Park in conserving an important economic fishery are offered as a means of informing the development of a targeted collaborative approach to enhance the management of the TCMP.

\subsection{Scorecard Results}

While the TCMP's performance increased over the 10-year period between 2007 and 2016, especially with regard to Context, Inputs and Outputs, there is still considerable room for improvement. This is particularly evident in the assessment of Planning, Process, and Outcomes. Furthermore, management practices and outcomes are still deficient when considering all the previously stated goals of the TCMP. In order to increase overall effectiveness, the MPA should be evaluated with relative frequency (ideally every two to three years) to improve opportunities for adaptive management and address issues in need of greater attention. The modified framework for assessing performance provides a suite of indicators from which the TCMP, in collaboration with interested partners could enhance the overall understanding of the progress being made (or not) within each of the six management categories, with particular emphasis on improving process related activities.

To enhance outcomes addressing the goals of public engagement, awareness and education, after each monitoring and evaluation cycle, a series of meetings should be held to discuss the findings with all relevant stakeholders and to consider how current management activities should be modified. This should be a joint effort undertaken with Park staff, even if facilitated by an external organization. It has been noted that before performance monitoring and evaluation can be well-integrated within the regular management practices, MPAs often need "major institutional reorientation at the policy level" [38]. Perhaps, by developing incentives, and engaging the community to expect performance information of the TCMP, managers could start conducting performance reports, allowing for a higher connection between the community and the management of this 
MPA again, as was the case in 2007.

\subsection{TCMP Performance in Achieving Stated Goals}

The TCMP has four main goals, of which it seems that only the second one (sustain economic benefits from the use of existing natural resources) is being achieved. The other three goals relate to marine conservation, public awareness and resources management, and public education and engagement.

Goal 1: Enhance conservation and management of biological diversity of the area.

Regarding the first goal, monitoring of several biophysical indicators has been conducted with relative frequency, mostly by external organizations or during ad hoc external research. However, the purpose behind these efforts seemed to have had no specific connection with improving TCMP management actions. There is an apparent disconnect between management and monitoring in the TCMP, limiting any opportunity for the implementation of adaptive management. This could be from the lack of a requirement by external researchers to provide the TCMP managers with their research proposal or their findings after completing their research. Furthermore, when research relevant to the TCMP is completed, it may not be published or the TCMP managers may not be aware that it has been published or have access to the publication, even if the data could be of use. In addition, the TCMP does not generally conduct research as part of its own activities.

Goal 2: Sustain economic benefits from the use of existing natural resources.

Emphasis on achieving Goal 2 has been the main focus of TCMP staff. According to observations in the area, most of the TCMP resources, staff, and budget are used to collect fees from boats visiting the TCMP, and to maintain the moorings. These economic benefits are the major source of funding of the MPA and staff salaries, and no doubt account for the attention given to this goal. Given the array of different expertise that would be needed to monitor progress towards the other stated goals, it would seem likely that a higher budget and additional staff will be needed if all of the goals become the focus of the Park management. Alternately, the re-structuring of current resources and workplans could be explored as well as developing more collaborative and formal linkages with external organizations that explicitly specify how their activities could contribute towards enhanced management of the Park.

Goal 3 and Goal 4: Increase public awareness of environmental issues and create a strong resources management system; and contribute to public education to increase engagement and achieve the objectives of the management plan.

The focus on these goals was very evident during the draft of the management plan. However, after the plan was drafted and finally accepted, activities relating to its achievement appeared to have been dropped. During the drafting of the management plan, it was noted that management of the TCMP "should be people-centered and participatory". It was also stated that two particularly relevant aspects were public education and monitoring [33]. However, the priority 
documents that were generated in 2007 mostly targeted visitors instead of the local community. Other expected outputs such as educational materials for school children were similarly not given priority. Finally and as noted above, research plans involving the TCMP (including surveys and analyses) are not developed or implemented by the TCMP and as such, do not play a key role in increasing public awareness and education about the resource management system for the TCMP.

The measures identified in the management plan aimed to increase the effectiveness of the management of the Park. However, it seems that they were not, or only partially, implemented. In 2002, Day, Hockings, \& Jones stated that "while monitoring and evaluation programs are supported in principle, they often get displaced by more 'urgent' (though often less important) day-to-day management activities" [39]. We suggest that this displacement could also happen at the level of goals. In the case of the TCMP, it seems monitoring activities and performance evaluations for three of the four goals identified for the Park were displaced by the need to maintain an adequate mooring systems so as to obtain economic benefits from tourism inside the MPA. Perhaps, if external funding (not originating from the fees collected inside the MPA) was secured on an annual basis, a higher focus on achieving the remaining goals would be developed. Until then, it is possible that major efforts at TCMP will be directed towards Goal 2.

\subsection{TCMP Effectiveness Based on Conch Density}

Results obtained on density and abundance of queen conch showed no significant difference inside and outside of the Park, even though conch had a higher density inside the TCMP borders than in nonprotected areas around Union Island. However, it is important to note that overall conch abundance has been reported as decreasing in the area as a result of overfishing, according to local knowledge [29]. As such, the TCMP could potentially have cushioned that decrease, contributing to the conservation of this species although not from a statistically significant perspective.

It is well known that excessive fishing pressure is usually responsible for conch decrease in multiple Caribbean countries [38]. However, the TCMP is a no-take MPA, and as such, it should be reasonable to discount conch fishing as a reason underlying the apparent lack of influence of the TCMP on the conservation of this species within the Park boundaries. Nevertheless, it is also known in the community and by the TCMP Rangers that some illegal fishing activities are still occurring inside the TCMP, so fishing activities could partially explain the results obtained. On the other hand, water quality could also be having major impacts on the abundance of this species. Conch are very sensitive to water quality changes due to their specific habitat requirements [40]. It is important to remember that the TCMP was originally created with tourism increase purposes. However, few measures to manage tourism activities were taken at the time, and the management plan does not include regulations for tourism except for the de- 
signation of special zones for anchoring [30]. According to a recent study by Reed, about 50,000 visitors and about 8,600 yachts entered the TCMP in 2015 [41]. It is known that vessels visiting the MPA could be decreasing water quality levels due to sewage waste generated by these vessels, and therefore regulations such as holding tank release restrictions have been recommended. Given the decrease in water quality caused by some twenty years of non-managed tourism activities, it is conceivable that this could be an important cause for the lack of effect of the TCMP regarding queen conch conservation.

Currently, the TCMP is in the process of implementing a yacht management plan to reduce the impacts that anchoring has inside the MPA, including tourism-oriented management measures for the first time [41]. This plan calls for enhanced water quality monitoring, as well as data collection on yacht impacts. It is also likely that this information will contribute to a better understanding of the carrying capacity inside the MPA for tourism. In addition, by analyzing water quality data and yacht abundance, poor water quality or degraded areas could be identified [41].

In order to ensure the health of the marine ecosystem and that adequate management is being implemented, it is essential to continue monitoring marine life, as well as other indicators such as water quality. We contend that the adapted framework can serve as an improved guide for ensuring all six management categories and four outcomes are tracked using indicators that provide needed data for informed decision making and adaptive management. However, recognizing the limited resources, dependence on external expertise and funding that limits implementation of a planned monitoring program, at a minimum, a focus on indicators tracking TCMP goals (Table 6) should be explicitly guiding monitoring decisions undertaken by Park staff or in discussions with external organizations. If monitoring continues and the necessary measures to preserve this area are taken (e.g. the successful implementation of a yacht management plan), the TCMP could significantly contribute to the conservation of multiple marine species such as conch, corals, and others as well as enhance the economic benefits to be obtained from a well-managed marine ecosystem.

The adapted framework developed in this study can certainly be used to evaluate other MPAs in order to test their effectiveness as management measures. The use of the adapted framework should be followed by the identification of a set of indicators that could be measured in the MPA to track its progress over time. These indicators might be different from the ones presented in this study, as they should fit the MPA goals, challenges, and management capacity. Considering that only $33 \%$ of the worlds MPAs could be truly effective, the need to evaluate them in a comprehensive manner is clear. In order to achieve the desired outcomes from the implementation of MPAs, these assessments should be conducted, so their performance can be improved.

\section{Conclusions}

MPAs have been found to be effective tools for marine conservation when they 
are adequately designated and managed. Management challenges encountered at the TCMP need to be overcome for it to achieve its full potential. For this purpose, the evaluation of the TCMP's effectiveness needs to be carried out with relative frequency to be able to determine the management actions that need improvement to reach the desired goals. In addition, it would be critical that the TCMP does not lose the perspective on the goals that they were originally trying to achieve. Currently, the TCMP needs to improve their planning, process, and outcomes in terms of their management actions, as well as to improve their monitoring strategies, and their ability to incorporate research data into their management actions. In addition, the TCMP needs to develop a higher focus on education, stakeholder participation, and stakeholder engagement.

It is essential to develop the necessary tools and platforms to promote integrated planning and implementation, collaboration, and information sharing between managers, external researchers and the TCMP staff, and between the community and the TCMP staff. In addition, it is important to develop strategies in which an annual budget for the management of the TCMP can be secured, and it is important that this is not only linked to tourism visitation. Tourism threats should be further identified and included as part of the management plan in order to reduce them. The carrying capacity of this MPA should also be determined in order to promote the sustainable use of the TCMP. Furthermore, the enforcement capacity of the TCMP should improve, as currently its staff does not have the authority to fine infractions occurring in the area, such as anchoring in restricted areas. Finally, the enforcement capacity of the TCMP should cover all regulations and monitoring of activities that are necessary to focus on the achievement of their goals.

Meeting current management, conservation, and socioeconomic needs of the MPA, investing in research activities, using available data to improve management, and conducting performance evaluations are the only way in which the TCMP will be able to become a successful and fully operational MPA at a time when effective marine management and protection are urgently required. Finally, the results of the evaluation conducted in this study can provide insights and lessons for other MPAs and managers. The authors encourage the use of the adapted scorecard as well as the identification of recommended indicators to evaluate other MPAs in order to enhance the overall performance of MPAs around the globe, and to encourage the adequate conservation of our marine resources.

\section{Acknowledgements}

Part of this study was conducted under the Eastern Caribbean Marine Managed Areas Network (ECMMAN) Project, in collaboration with the Tobago Cays Marine Park, the National Parks and Beaches Authority of St. Vincent and the Grenadines, and Sustainable Grenadines Inc. The authors would like to thank Sustainable Grenadines Inc., the TCMP staff and the community of Union Island 
for their support during this research.

\section{References}

[1] Halpern, B.S., Walbridge, S., Selkoe, K.A., Kappel, C.V., Micheli, F., D’agrosa, C., Bruno, J.F., Casey, K.S., Ebert, C., Fox, H.E. and Fujita, R. (2008) A Global Map of Human Impact on Marine Ecosystems. Science, 319, 948-952. https://doi.org/10.1126/science.1149345

[2] Halpern, B.S., Longo, C., Hardy, D., McLeod, K.L., Samhouri, J.F., Katona, S.K., Kleisner, K., Lester, S.E., O’Leary, J., Ranelletti, M. and Rosenberg, A.A. (2012) An Index to Assess the Health and Benefits of the Global Ocean. Nature, 488, 615-620. https://doi.org/10.1038/nature11397

[3] Vitousek, P.M., Mooney, H.A., Lubchenco, J. and Melillo, J.M. (1997) Human Domination of Earth's Ecosystems. Science, 277, 494-499.

https://doi.org/10.1126/science.277.5325.494

[4] Crutzen, P.J. (2006) The "Anthropocene". In Earth System Science in the Anthropocene. Springer, Berlin, 13-18. https://doi.org/10.1007/3-540-26590-2_3

[5] Wu, Z., Yu, Z., Song, X., Li, Y., Cao, X. and Yuan, Y. (2016) A Methodology for Assessing and Mapping Pressure of Human Activities on Coastal Region Based on Stepwise Logic Decision Process and GIS Technology. Ocean \& Coastal Management, 120, 80-87. https://doi.org/10.1016/j.ocecoaman.2015.11.016

[6] Madin, E.M., Dill, L.M., Ridlon, A.D., Heithaus, M.R. and Warner, R.R. (2016) Human Activities Change Marine Ecosystems by Altering Predation Risk. Global Change Biology, 22, 44-60. https://doi.org/10.1111/gcb.13083

[7] Borja, A., Elliott, M., Carstensen, J., Heiskanen, A.S. and Van, B.W. (2010) Marine Management-Towards an Integrated Implementation of the European Marine Strategy Framework and the Water Framework Directives. Marine Pollution Bulletin, 60, 2175-2186. https://doi.org/10.1016/j.marpolbul.2010.09.026

[8] Douvere, F. (2008) The Importance of Marine Spatial Planning in Advancing Ecosystem-Based Sea Use Management. Marine Policy, 32, 762-771.

https://doi.org/10.1016/j.marpol.2008.03.021

[9] Wondolleck, J.M. and Yaffee, S.L. (2017) Drawing Lessons from Experience in Marine Ecosystem-Based Management. In: Wondolleck, J. and Yaffee, S., Eds., Marine Ecosystem-Based Management in Practice, Island Press, Center for Resource Economics, Washington DC, 1-12. https://doi.org/10.5822/978-1-61091-800-8_1

[10] Gunderson, A.R., Armstrong, E.J. and Stillman, J.H. (2016) Multiple Stressors in a Changing World: the Need for an Improved Perspective on Physiological Responses to the Dynamic Marine Environment. Annual Review of Marine Science, 8, $357-$ 378. https://doi.org/10.1146/annurev-marine-122414-033953

[11] Micheli, F., Saenz-Arroyo, A., Greenley, A., Vazquez, L., Espinoza, M.J.A., Rossetto, M. and Leo, G.A. (2012) Evidence that Marine Reserves Enhance Resilience to Climatic Impacts. PLoS One, 7, 1-8. https://doi.org/10.1371/journal.pone.0040832

[12] Barner, A.K., Lubchenco, J., Costello, C., Gaines, S.D., Leland, A., Jenks, B., Murawski, S., Schwaab, E. and Spring, M. (2015) Solutions for Recovering and Sustaining the Bounty of the Ocean: Combining Fishery Reforms, Rights-Based Fisheries Management, and Marine Reserves. Oceanography, 28, 252-263. https://doi.org/10.5670/oceanog.2015.51

[13] Hoegh-Guldberg, O. and Bruno, J.F. (2010) The Impact of Climate Change on the World's Marine Ecosystems. Science, 328, 1523-1528. https://doi.org/10.1126/science.1189930 
[14] Dudley, N. (2008) Guidelines for Applying Protected Area Management Categories. International Union for Conservation of Nature, Gland VD.

[15] Agardy, M.T. (1994) Advances in Marine Conservation: The Role of Marine Protected Areas. Trends in Ecology \& Evolution, 9, 267-270.

https://doi.org/10.1016/0169-5347(94)90297-6

[16] Halpern, B.S. and Warner, R.R. (2002) Marine Reserves Have Rapid and Lasting Effects. Ecology Letters, 5, 361-366. https://doi.org/10.1046/j.1461-0248.2002.00326.x

[17] Hughes, T.P., Baird, A.H., Bellwood, D.R., Card, M., Connolly, S.R., Folke, C. and Roughgarden, J. (2003) Climate Change, Human Impacts, and the Resilience of Coral Reefs. Science, 301, 929-933. https://doi.org/10.1126/science.1085046

[18] Boersma, P.D. and Parrish, J.K. (1999) Limiting Abuse: Marine Protected Areas, a Limited Solution. Ecological Economics, 31, 287-304. https://doi.org/10.1016/S0921-8009(99)00085-3

[19] Jameson, S.C., Tupper, M.H. and Ridley, J.M. (2002) The Three Screen Doors: Can Marine "Protected" Areas Be Effective? Marine Pollution Bulletin, 44, 1177-1183. https://doi.org/10.1016/S0025-326X(02)00258-8

[20] Agardy, T., Sciara, G.N. and Christie, P. (2011) Mind the Gap: Addressing the Shortcomings of Marine Protected Areas through Large Scale Marine Spatial Planning. Marine Policy, 35, 226-232. https://doi.org/10.1016/j.marpol.2010.10.006

[21] Claudet, J., Pelletier, D., Jouvenel, J.Y., Bachet, F. and Galzin, R. (2006) Assessing the Effects of Marine Protected Area (MPA) on a Reef Fish Assemblage in a Northwestern Mediterranean Marine Reserve: Identifying Community-Based Indicators. Biological Conservation, 130, 349-369. https://doi.org/10.1016/j.biocon.2005.12.030

[22] MPAtlas (2016) Discover the World's Marine Protected Areas. Marine Conservation Institute, Seattle.

[23] Pomeroy, R.S., Watson, L.M., Parks, J.E. and Cid, G.A. (2005) How Is Your MPA Doing? A Methodology for Evaluating the Management Effectiveness of Marine Protected Areas. Ocean \& Coastal Management, 48, 485-502. https://doi.org/10.1016/j.ocecoaman.2005.05.004

[24] Selig, E.R. and Bruno, J.F. (2010) A Global Analysis of the Effectiveness of Marine Protected Areas in Preventing Coral Loss. PLoS One, 5, Article ID: e9278. https://doi.org/10.1371/journal.pone.0009278

[25] Staub, F. and Hatziolos, M.E. (2004) Score Card to Assess Progress in Achieving Management Effectiveness Goals for Marine Protected Areas. World Bank, Washington DC.

[26] Stelzenmuller, V. and Pinnegar, J.K. (2011) Monitoring Fisheries Effects of Marine Protected Areas: Current Approaches and the Need for Integrated Assessments. In Marine Protected Areas: A Multidisciplinary Approach. Cambridge University Press, New York, 186-189. https://doi.org/10.1017/cbo9781139049382.011

[27] The Nature Conservancy (2016) St. Vincent and the Grenadines' Coral Reef Report Card 2016. The Nature Conservancy, Arlington, 8. https://www.nature.org/media/coral-reef-report-cards/SVG_Report_Card_2016_W ebLowRes.pdf

[28] World Travel and Tourism Council (WTTC) (2017) Travel and Tourism Economic Impact Caribbean. World Travel and Tourism Council, London.

https://www.wttc.org/-/media/files/reports/economic-impact-research/regions-2017 /caribbean2017.pdf 
[29] Hoggarth, D. (2007) Tobago Cays Marine Park 2007-2009 Management Plan. Organisation of Eastern Caribbean States, and Environment and Sustainable Development Unit, St. Lucia.

[30] United Nations Environment Programme (2014) Proposed Areas for Inclusion in the SPAW List. Annotated Format for Presentation Report for: Tobago Cays Marine Park, Saint Vincent and the Grenadines. United Nations Environment Programme, Kingston.

[31] The Census Office (2012) 2012 Population \& Housing Census: Preliminary Report. St. Vincent \& the Grenadines Population \& Housing. Central Planning Division, Ministry of Finance and Economic Planning, Suitland.

[32] Deschamps, A., Desrochers, A. and Klomp, K.D. (2003) A Rapid Assessment of the Horseshoe Reef, Tobago Cays Marine Park, St. Vincent, West Indies (Stony Corals, Algae and Fishes). Atoll Research Bulletin, 496, 438-458. https://doi.org/10.5479/si.00775630.496-24.438

[33] Ecoengineering Caribbean Limited (2007) Environmental and Socio-Economic Studies for OPAAL Demonstration Sites. Tobago Cays Site Report, St. Vincent and the Grenadines. (Eco Report No. 06). Organisation of Eastern Caribbean States Environment and Sustainable Development Unit, St. Augustine, Trinidad, West Indies.

[34] Phillips, M. and Hewitt, K. (2015) Eastern Caribbean Marine Managed Areas Network (ECMANN) Project. Component 3: Prioritizing Sites in the SVG MMA System for Application of Key Management Actions. Sustainable Grenadines Incorporation, St. Vincent, 11.

[35] Food and Agriculture Organization (2007) Regional Workshop on the Monitoring and Management of Queen Conch, Strombus gigas (FAO Fisheries Report No. 832) Food and Agriculture Organization, Kingston, 186.

[36] Egan, B.D. (1985) Aspects of the Reproductive Biology of Strombus Gigas. University of British Columbia, Vancouver.

[37] Clark, S.A., Danylchuk, A.J. and Freeman, B.T. (2005) The Harvest of Juvenile Queen Conch (Strombus gigas) off Cape Eleuthera, Bahamas: Implications for the Effectiveness of a Marine Reserve. Proceedings of the Gulf and Caribbean Fisheries Institute, 56, 705-714.

[38] Townsend, J. (2012) Petition to List Queen Conch (Strombas gigas) under the Endangered Species Act. WildEarth Guardians, Santa Fe.

[39] Day, J., Hockings, M. and Jones, G. (2002) Measuring Effectiveness in Marine Protected Areas: Principles and Practice. World Congress on Aquatic Protected Areas, 18, 401-404.

[40] Appeldoorn, R.S., Gonzalez, E.C., Glazer, R. and Prada, M. (2011) Applying EBM to Queen Conch Fisheries in the Caribbean. In: Fanning, L., Mahon, R. and Mcconney, P., Eds., Towards Marine Ecosystem-Based Management in the Wider Caribbean, Amsterdam University Press, Amsterdam, 177-186.

[41] Reed, M. (2016) Adaptive Moorings Management Plan for Tobago Cays Marine Park, Saint Vincent and the Grenadines. Sustainable Grenadines Incorporation and The Nature Conservancy for Tobago Cays Marine Park with Funding from United States Agency for International Development, Arlington. 


\section{Appendix 1}

\section{Criteria for scoring MPA effectiveness}

\begin{tabular}{|c|c|c|c|c|}
\hline $\begin{array}{l}\text { Questions relating } \\
\text { to Context }\end{array}$ & Criteria score 0 & Criteria score 1 & Criteria score 2 & Criteria score 3 \\
\hline $\begin{array}{l}\text { Q1. Legal Status: Does the MPA } \\
\text { have legal status? }\end{array}$ & $\begin{array}{l}\text { The MPA is not } \\
\text { legally recognized. }\end{array}$ & $\begin{array}{l}\text { The government has } \\
\text { agreed to pursue legal } \\
\text { recognition. }\end{array}$ & $\begin{array}{l}\text { The MPA is in the } \\
\text { process of being } \\
\text { legally recognized. }\end{array}$ & $\begin{array}{l}\text { The MPA has been } \\
\text { legally recognized. }\end{array}$ \\
\hline $\begin{array}{l}\text { Q2. MPA regulations: Are } \\
\text { unsustainable human activities } \\
\text { controlled? }\end{array}$ & $\begin{array}{l}\text { There are no } \\
\text { regulations in place. }\end{array}$ & $\begin{array}{l}\text { Mechanisms exist but } \\
\text { not effectively } \\
\text { implemented. }\end{array}$ & $\begin{array}{l}\text { Mechanisms exist } \\
\text { but not fully } \\
\text { implemented. }\end{array}$ & $\begin{array}{l}\text { Mechanisms exist and } \\
\text { are being effectively } \\
\text { implemented. }\end{array}$ \\
\hline $\begin{array}{l}\text { Q3. Law enforcement: Can } \\
\text { staff sufficiently enforce } \\
\text { regulations? }\end{array}$ & $\begin{array}{l}\text { No ability/capacity to } \\
\text { enforce regulations. }\end{array}$ & $\begin{array}{l}\text { Limited ability/capacity } \\
\text { to enforce regulations. }\end{array}$ & $\begin{array}{l}\text { Acceptable ability/ } \\
\text { capacity to enforce } \\
\text { regulations. }\end{array}$ & $\begin{array}{l}\text { Excellent ability/ } \\
\text { capacity to enforce } \\
\text { regulations. }\end{array}$ \\
\hline $\begin{array}{l}\text { Q4. MPA boundaries: Are } \\
\text { boundaries known to staff } \\
\text { and stakeholders? }\end{array}$ & $\begin{array}{l}\text { The boundaries are not } \\
\text { known to either MPA } \\
\text { staff or stakeholders }\end{array}$ & $\begin{array}{l}\text { The boundaries are only } \\
\text { known to MPA authority } \\
\text { but not to stakeholders. }\end{array}$ & $\begin{array}{l}\text { Boundaries are known } \\
\text { to stakeholders and } \\
\text { authorities but are not } \\
\text { demarcated. }\end{array}$ & $\begin{array}{l}\text { Boundaries are known } \\
\text { to all and demarcated } \\
\text { physically. }\end{array}$ \\
\hline $\begin{array}{l}\text { Q5. Integration of the MPA in } \\
\text { a larger coastal management plan: } \\
\text { Is the MPA part of a larger } \\
\text { coastal management plan? }\end{array}$ & $\begin{array}{l}\text { No discussion on } \\
\text { integrating MPA into } \\
\text { a larger coastal } \\
\text { management plan. }\end{array}$ & $\begin{array}{l}\text { Some discussion on } \\
\text { integrating MPA into } \\
\text { larger coastal } \\
\text { management plan. }\end{array}$ & $\begin{array}{l}\text { MPA is in the process } \\
\text { of being integrated } \\
\text { into a larger coastal } \\
\text { management plan. }\end{array}$ & $\begin{array}{l}\text { MPA is part of a larger } \\
\text { coastal management } \\
\text { plan. }\end{array}$ \\
\hline $\begin{array}{l}\text { Q6. Resource inventory: Is } \\
\text { there enough information to } \\
\text { manage the area? }\end{array}$ & $\begin{array}{l}\text { No information } \\
\text { available } \\
\text { to effectively } \\
\text { manage the } \\
\text { MPA. }\end{array}$ & $\begin{array}{l}\text { Insufficient information } \\
\text { available to effectively } \\
\text { manage the MPA. }\end{array}$ & $\begin{array}{l}\text { Sufficient prior } \\
\text { information exists to } \\
\text { manage the MPA but } \\
\text { current monitoring is } \\
\text { limited. }\end{array}$ & $\begin{array}{l}\text { Sufficient prior and } \\
\text { current information } \\
\text { exists to manage the } \\
\text { MPA with ongoing } \\
\text { monitoring. }\end{array}$ \\
\hline Questions relating to Planning & Criteria score 0 & Criteria score 1 & Criteria score 2 & Criteria score 3 \\
\hline $\begin{array}{l}\text { Q8. MPA objectives: Have } \\
\text { objectives been agreed? }\end{array}$ & $\begin{array}{l}\text { No firm MPA } \\
\text { objectives have } \\
\text { been agreed. }\end{array}$ & $\begin{array}{l}\text { The MPA has agreed } \\
\text { objectives. }\end{array}$ & $\begin{array}{l}\text { MPA objectives } \\
\text { agreed to and partially } \\
\text { implemented. }\end{array}$ & $\begin{array}{l}\text { MPA objectives agreed } \\
\text { to and managed to } \\
\text { fully meet them. }\end{array}$ \\
\hline $\begin{array}{l}\text { Q9. Management Plan: Is there } \\
\text { a management plan, and is it } \\
\text { being implemented? }\end{array}$ & $\begin{array}{l}\text { There is no } \\
\text { management plan } \\
\text { for the MPA. }\end{array}$ & $\begin{array}{l}\text { A management plan } \\
\text { is being developed } \\
\text { or exists but is not } \\
\text { implemented. }\end{array}$ & $\begin{array}{l}\text { Approved management } \\
\text { plan exists but is only } \\
\text { partially implemented. }\end{array}$ & $\begin{array}{l}\text { Approved management } \\
\text { plan exists and is being } \\
\text { fully implemented. }\end{array}$ \\
\hline Questions relating to Input & Criteria score 0 & Criteria score 1 & Criteria score 2 & Criteria score 3 \\
\hline $\begin{array}{l}\text { Q10. Research: Is there a } \\
\text { program of management- } \\
\text { oriented survey and } \\
\text { research work? }\end{array}$ & $\begin{array}{l}\text { There is no survey or } \\
\text { research work taking } \\
\text { place in the MPA. }\end{array}$ & $\begin{array}{l}\text { There is some ad hoc } \\
\text { survey and research } \\
\text { work occurring. }\end{array}$ & $\begin{array}{l}\text { Considerable survey } \\
\text { and research work but } \\
\text { it is not guided by the } \\
\text { MPA needs. }\end{array}$ & $\begin{array}{l}\text { Integrated program of } \\
\text { survey and research work } \\
\text { explicitly guided by MPA } \\
\text { needs. }\end{array}$ \\
\hline $\begin{array}{l}\text { Q11. Staff numbers: Are } \\
\text { there enough people employed } \\
\text { to manage the MPA? }\end{array}$ & There is no staff. & $\begin{array}{l}\text { Staff numbers are } \\
\text { inadequate for critical } \\
\text { management activities. }\end{array}$ & $\begin{array}{l}\text { Staff numbers are below } \\
\text { optimum level for critical } \\
\text { management activities. }\end{array}$ & $\begin{array}{l}\text { Staff numbers are adequate } \\
\text { for the management needs of } \\
\text { the site. }\end{array}$ \\
\hline $\begin{array}{l}\text { Q12. Current Budget: Is the } \\
\text { current budget sufficient? }\end{array}$ & $\begin{array}{l}\text { There is no budget } \\
\text { for the MPA. }\end{array}$ & $\begin{array}{l}\text { The available budget } \\
\text { is inadequate for basic } \\
\text { management needs. }\end{array}$ & $\begin{array}{l}\text { Available budget meets } \\
\text { basic management } \\
\text { needs. }\end{array}$ & $\begin{array}{l}\text { Available budget is sufficient } \\
\text { and meets full management } \\
\text { needs of the MPA. }\end{array}$ \\
\hline
\end{tabular}




\section{Continued}

Q21. How are the biophysical

indicators being measured/

monitored? (Maximum score

$=2$ ):

\begin{tabular}{|c|c|c|c|c|}
\hline - Temporally & No indicators measured. & $\begin{array}{l}\text { Measured only after the } \\
\text { MPA was implemented. }\end{array}$ & $\begin{array}{l}\text { Measured before and after } \\
\text { the MPA was } \\
\text { implemented. }\end{array}$ & \\
\hline - Spatially & No indicators measured. & $\begin{array}{l}\text { Measured only inside the } \\
\text { MPA boundaries. }\end{array}$ & $\begin{array}{l}\text { Measured inside and } \\
\text { outside of the MPA } \\
\text { boundaries. }\end{array}$ & \\
\hline $\begin{array}{l}\text { Q22. How frequently are the } \\
\text { biophysical indicators being } \\
\text { measured? }\end{array}$ & $\begin{array}{l}\text { Indicators not } \\
\text { measured. }\end{array}$ & $\begin{array}{l}\text { Less frequent than every } \\
\text { three years. }\end{array}$ & Every two to three years. & On an annual basis. \\
\hline
\end{tabular}




\section{Continued}

Q23. Monitoring and

evaluation: Are

socioeconomic indicators

monitored and evaluated

(M\&E)?
There is no $\mathrm{M}$ \& $\mathrm{E}$ of socioeconomic context of the MPA.
There is some but mostly

ad hoc $\mathrm{M} \& \mathrm{E}$ and no

overall strategy or

regular data collection.
There is an agreed and implemented M \& E system but results are not used well for management.
A good M\&E system exists, is well implemented, and results are used in adaptive management.

Q24. Socioeconomic

Parameters: Scored on the basis of 2 Bonus Points each if present.

\section{Criteria scoring not Criteria scoring not} relevant.
Criteria scoring not relevant
Criteria scoring not relevant
Q25. Monitoring and evaluation: Are governance indicators monitored and evaluated $(\mathrm{M} \& \mathrm{E})$ ?
There is no $\mathrm{M} \& \mathrm{E}$ of socioeconomic contex of the MPA.
There is some but mostly ad hoc $\mathrm{M} \& \mathrm{E}$ and no overall strategy or regular data collection.
There is an agreed and implemented M \& E system but results are not used well for management.
A good M \& E system exists, is well implemented, and results are used in adaptive management.

Q26. Governance Parameters: Scored on the basis of 2 Bonus Points each if present.

Criteria scoring not relevant.

\section{Criteria scoring not} relevant.
Criteria scoring not relevant.
Criteria scoring not relevant.

\begin{tabular}{|c|c|c|c|c|}
\hline Questions relating to Outputs & Criteria score 0 & Criteria score 1 & Criteria score 2 & Criteria score 3 \\
\hline $\begin{array}{l}\text { Q27. Context indicators: } 2 \\
\text { Bonus Points each if present. }\end{array}$ & $\begin{array}{l}\text { Criteria scoring not } \\
\text { relevant. }\end{array}$ & $\begin{array}{l}\text { Criteria scoring not } \\
\text { relevant. }\end{array}$ & $\begin{array}{l}\text { Criteria scoring not } \\
\text { relevant. }\end{array}$ & $\begin{array}{l}\text { Criteria scoring not } \\
\text { relevant. }\end{array}$ \\
\hline $\begin{array}{l}\text { Q28. Product and Services: } \\
\text { Bonus point(s) if present }\end{array}$ & $\begin{array}{l}\text { Criteria scoring not } \\
\text { relevant. }\end{array}$ & $\begin{array}{l}\text { Criteria scoring not } \\
\text { relevant. }\end{array}$ & $\begin{array}{l}\text { Criteria scoring not } \\
\text { relevant. }\end{array}$ & $\begin{array}{l}\text { Criteria scoring not } \\
\text { relevant. }\end{array}$ \\
\hline $\begin{array}{l}\text { Q29. Stakeholder } \\
\text { engagement: Are mechanisms } \\
\text { available to ensure } \\
\text { stakeholder participation? } \\
(\text { Maximum score }=2)\end{array}$ & $\begin{array}{l}\text { There are no } \\
\text { mechanisms for } \\
\text { stakeholder } \\
\text { participation in } \\
\text { management activities. }\end{array}$ & $\begin{array}{l}\text { There are some } \\
\text { mechanisms for } \\
\text { stakeholder participation } \\
\text { in management activities } \\
\text { but inadequate. }\end{array}$ & $\begin{array}{l}\text { There are adequate } \\
\text { mechanisms for } \\
\text { stakeholder participation } \\
\text { in management } \\
\text { activities. }\end{array}$ & \\
\hline $\begin{array}{l}\text { Q30. Environmental } \\
\text { education for stakeholders: } \\
\text { Have education activities } \\
\text { been developed? (Maximum } \\
\text { score }=2 \text { ) }\end{array}$ & $\begin{array}{l}\text { No education activities } \\
\text { available for } \\
\text { stakeholders. }\end{array}$ & $\begin{array}{l}\text { Some education activities } \\
\text { available for } \\
\text { stakeholders. }\end{array}$ & $\begin{array}{l}\text { Sufficient education } \\
\text { activities available for } \\
\text { stakeholders. }\end{array}$ & \\
\hline $\begin{array}{l}\text { Q31. Management activities: } \\
\text { Have critical management } \\
\text { activities been improved to } \\
\text { address threats? (Maximum } \\
\text { score }=2 \text { ) }\end{array}$ & $\begin{array}{l}\text { Essential management } \\
\text { activities have not } \\
\text { improved to address } \\
\text { threats. }\end{array}$ & $\begin{array}{l}\text { Some measures have } \\
\text { been taken to improve } \\
\text { management activities. }\end{array}$ & $\begin{array}{l}\text { Management activities } \\
\text { have been sufficiently } \\
\text { improved. }\end{array}$ & \\
\hline $\begin{array}{l}\text { Q32. Visitor facilities: Does } \\
\text { the MPA have adequate } \\
\text { visitor facilities? }\end{array}$ & $\begin{array}{l}\text { There are no visitor } \\
\text { facilities and services. }\end{array}$ & $\begin{array}{l}\text { Visitor facilities and } \\
\text { services are } \\
\text { inappropriate for current } \\
\text { levels of visitation. }\end{array}$ & $\begin{array}{l}\text { There are some visitor } \\
\text { facilities and services, } \\
\text { but they could be } \\
\text { improved. }\end{array}$ & $\begin{array}{l}\text { Visitor facilities and } \\
\text { services are sufficient for } \\
\text { current levels of } \\
\text { visitation. }\end{array}$ \\
\hline $\begin{array}{l}\text { Q33. Fees: If fees are applied, } \\
\text { do they help MPA } \\
\text { management? }\end{array}$ & Fees are not collected. & $\begin{array}{l}\text { Fees are collected but } \\
\text { they go to central } \\
\text { government. }\end{array}$ & $\begin{array}{l}\text { Fees are collected, but } \\
\text { they go to the local } \\
\text { authority. }\end{array}$ & $\begin{array}{l}\text { Fees for visiting the } \\
\text { MPA help to support the } \\
\text { MPA. }\end{array}$ \\
\hline
\end{tabular}




\section{Continued}

\begin{tabular}{|c|c|c|c|c|}
\hline $\begin{array}{l}\text { Q34. Staff training: Is } \\
\text { the staff adequately } \\
\text { trained? }\end{array}$ & $\begin{array}{l}\text { The staff is not trained } \\
\text { for required tasks. }\end{array}$ & $\begin{array}{l}\text { The staff training and } \\
\text { skills are low for required } \\
\text { tasks. }\end{array}$ & $\begin{array}{l}\text { The staff training and } \\
\text { skills are adequate for } \\
\text { most tasks. }\end{array}$ & $\begin{array}{l}\text { The staff training and } \\
\text { skills are acceptable for all } \\
\text { tasks. }\end{array}$ \\
\hline $\begin{array}{l}\text { Questions relating to } \\
\text { Outcomes }\end{array}$ & Criteria score 0 & Criteria score 1 & Criteria score 2 & Criteria score 3 \\
\hline $\begin{array}{l}\text { Q35. Objectives: Have } \\
\text { MPA objectives been } \\
\text { addressed? }\end{array}$ & $\begin{array}{l}\text { Management objectives } \\
\text { have not been addressed. }\end{array}$ & $\begin{array}{l}\text { Few management } \\
\text { objectives have been } \\
\text { addressed. }\end{array}$ & $\begin{array}{l}\text { Most management } \\
\text { objectives have been } \\
\text { addressed. }\end{array}$ & $\begin{array}{l}\text { Management objectives } \\
\text { have been significantly } \\
\text { addressed. }\end{array}$ \\
\hline $\begin{array}{l}\text { Q36. Threats: Have } \\
\text { threats been reduced? }\end{array}$ & Threats have increased. & $\begin{array}{l}\text { Threats have stayed } \\
\text { approximately the same. }\end{array}$ & $\begin{array}{l}\text { Some threats have been } \\
\text { reduced. }\end{array}$ & $\begin{array}{l}\text { Threats have been largely } \\
\text { reduced. }\end{array}$ \\
\hline $\begin{array}{l}\text { Q37. Resource } \\
\text { conditions: Have } \\
\text { resource conditions } \\
\text { improved? }\end{array}$ & $\begin{array}{l}\text { Resource conditions have } \\
\text { declined. }\end{array}$ & $\begin{array}{l}\text { Resource conditions have } \\
\text { stayed at the same levels. }\end{array}$ & $\begin{array}{l}\text { Resource conditions have } \\
\text { improved somewhat. }\end{array}$ & $\begin{array}{l}\text { Resource conditions have } \\
\text { improved significantly. }\end{array}$ \\
\hline $\begin{array}{l}\text { Q38. Community } \\
\text { welfare: Has } \\
\text { community welfare } \\
\text { improved? }\end{array}$ & $\begin{array}{l}\text { Livelihoods/standard of } \\
\text { living have declined. }\end{array}$ & $\begin{array}{l}\text { Livelihoods/standard of } \\
\text { living have stayed the } \\
\text { same. }\end{array}$ & $\begin{array}{l}\text { Livelihoods/standard of } \\
\text { living have improved } \\
\text { somewhat. }\end{array}$ & $\begin{array}{l}\text { Livelihoods/standard of } \\
\text { living have improved } \\
\text { significantly. }\end{array}$ \\
\hline $\begin{array}{l}\text { Q39. Environmental } \\
\text { awareness: Has } \\
\text { community } \\
\text { environmental } \\
\text { awareness improved? }\end{array}$ & $\begin{array}{l}\text { Community awareness of } \\
\text { environmental issues and } \\
\text { threats has declined. }\end{array}$ & $\begin{array}{l}\text { Community } \\
\text { environmental awareness } \\
\text { has stayed approximately } \\
\text { the same. }\end{array}$ & $\begin{array}{l}\text { Community } \\
\text { environmental awareness } \\
\text { has improved somewhat. }\end{array}$ & $\begin{array}{l}\text { Community } \\
\text { environmental awareness } \\
\text { has improved } \\
\text { significantly. }\end{array}$ \\
\hline $\begin{array}{l}\text { Q40. Compliance: Are } \\
\text { users complying with } \\
\text { MPA regulations? }\end{array}$ & $\begin{array}{l}\text { Less than } 25 \% \text { of users } \\
\text { comply with regulations. }\end{array}$ & $\begin{array}{l}25 \%-50 \% \text { of users } \\
\text { comply with regulations. }\end{array}$ & $\begin{array}{l}50 \%-75 \% \text { of users } \\
\text { comply with regulations. }\end{array}$ & $\begin{array}{l}\text { Over } 75 \% \text { of users comply } \\
\text { with regulations. }\end{array}$ \\
\hline $\begin{array}{l}\text { Q41. Stakeholder } \\
\text { satisfaction - Are the } \\
\text { stakeholders satisfied } \\
\text { with the process and } \\
\text { outputs of the MPA? }\end{array}$ & $\begin{array}{l}\text { Less than } 25 \% \text { of } \\
\text { stakeholders are satisfied } \\
\text { with the MPA. }\end{array}$ & $\begin{array}{l}25 \%-50 \% \text { of stakeholders } \\
\text { are satisfied with the } \\
\text { process and outputs of the } \\
\text { MPA. }\end{array}$ & $\begin{array}{l}50 \%-75 \% \text { of stakeholders } \\
\text { are satisfied with the } \\
\text { process and outputs of the } \\
\text { MPA. }\end{array}$ & $\begin{array}{l}\text { Over } 75 \% \text { of stakeholders } \\
\text { are satisfied with the } \\
\text { process and outputs of the } \\
\text { MPA. }\end{array}$ \\
\hline
\end{tabular}

Submit or recommend next manuscript to SCIRP and we will provide best service for you:

Accepting pre-submission inquiries through Email, Facebook, LinkedIn, Twitter, etc. A wide selection of journals (inclusive of 9 subjects, more than 200 journals)

Providing 24-hour high-quality service

User-friendly online submission system

Fair and swift peer-review system

Efficient typesetting and proofreading procedure

Display of the result of downloads and visits, as well as the number of cited articles

Maximum dissemination of your research work

Submit your manuscript at: http://papersubmission.scirp.org/

Orcontact ojms@scirp.org 